\title{
D-AREA COAL PILE RUNOFF BASIN SULFATE REDUCTION LITERATURE REVIEW AND FEASIBILITY REPORT (U)
}

September 25, 2001

\author{
M. A. Phifer \\ C. E. Turick \\ M. R. Millings
}

UNCLASSIFIED

Does Not Contain Unclassified Nuclear Information (UCNI)

ADC and Reviewing Official

M. K. Harris, Manager
Geo-Modeling
Environmental Restoration Technology Section

Westinghouse Savannah River Company

Savannah River Site

Aiken, SC 29801

Prepared for the US Department of Energy under Contract DE-AC09-96SR18500 
This document was prepared in conjunction with work accomplished under Contract No. DE-AC09-96SR18500 with the U. S. Department of Energy.

\section{DISCLAIMER}

This report was prepared as an account of work sponsored by an agency of the United States Government. Neither the United States Government nor any agency thereof, nor any of their employees, makes any warranty, express or implied, or assumes any legal liability or responsibility for the accuracy, completeness, or usefulness of any information, apparatus, product or process disclosed, or represents that its use would not infringe privately owned rights. Reference herein to any specific commercial product, process or service by trade name, trademark, manufacturer, or otherwise does not necessarily constitute or imply its endorsement, recommendation, or favoring by the United States Government or any agency thereof. The views and opinions of authors expressed herein do not necessarily state or reflect those of the United States Government or any agency thereof.

This report has been reproduced directly from the best available copy.

Available for sale to the public, in paper, from: U.S. Department of Commerce, National Technical Information Service, 5285 Port Royal Road, Springfield, VA 22161, phone: (800) 553-6847, fax: (703) 605-6900

email: orders@ ntis.fedworld.gov

online ordering: http://www.ntis.gov/support/index.html

Available electronically at http://www.doe.gov/bridge

Available for a processing fee to U.S. Department of Energy and its contractors, in paper, from: U.S. Department of Energy, Office of Scientific and Technical Information, P.O. Box 62, Oak Ridge, TN 37831-0062,

phone: (865)576-8401,

fax: (865)576-5728

email: $\underline{\text { reports@ adonis.osti.gov }}$ 


\section{D-AREA COAL PILE RUNOFF BASIN SULFATE REDUCTION LITERATURE REVIEW AND FEASIBILITY REPORT (U)}

Prepared By:

M. A. Phifer

Date

Environmental Restoration Technologies Section

Savannah River Technology Center

C. E. Turick

Date

Environmental Biotechnology Section

Savannah River Technology Center

M. R. Millings

Date

Environmental Restoration Technologies Section

Savannah River Technology Center

Technical Review By:

F. C. Sappington

Date

Environmental Restoration Technologies Section

Savannah River Technology Center

Approved By:

R. S. Aylward, Manager

Date

Environmental Restoration Technologies Section

Savannah River Technology Center 
Left Blank Intentionally 


\section{D-AREA COAL PILE RUNOFF BASIN SULFATE REDUCTION LITERATURE REVIEW AND FEASIBILITY REPORT (U)}

\subsection{EXECUTIVE SUMMARY}

The D-Area Coal Pile Runoff Basin (DCPRB) groundwater plume is acidic and contains heavy metals and sulfate. Portions of this plume near the source have a $\mathrm{pH}$ approaching 2.0 and heavy metal concentrations exceeding Maximum Contaminant Levels (MCLs) established by the National Primary Drinking Water Regulations. Remedial action for the groundwater contaminated by this RCRA/CERCLA unit will be required to mitigate the migration of highly contaminated groundwater towards adjacent surface water bodies.

The Environmental Restoration Division (ERD) requested the Savannah River Technology Center to perform a literature review to assess the feasibility of sulfate reduction as a means to remediate this DCPRB low $\mathrm{pH} / \mathrm{metals} / \mathrm{sulfate}$ groundwater plume. Sulfate reduction mediated by sulfate reducing bacteria $(\mathrm{SRB})$ results in the generation of hydrogen sulfide and bicarbonate and an increase in the $\mathrm{pH}$, which subsequently results in the precipitation of metal sulfides, hydroxides and carbonates.

Based upon this review it has been concluded that the DCPRB contaminated groundwater can be remediated with sulfate reduction combined with Monitored Natural Attenuation (MNA). In order to promote sulfate reduction some geochemical conditions need to be modified. An organic carbon substrate needs to be added, a base amendment may need to be added, and it is possible nitrogen and phosphate amendments may also need to be added in order to sustain and enhance SRB growth and promote the subsequent sulfate reduction remediation. Of the organic carbon substrates evaluated lactate, Hydrogen Release Compound (HRC), and soy or vegetable oil are considered to have the greatest potential for use. Of the potential base, phosphate, and nitrogen amendments evaluated, limestone, phosphate rock, and commercial fertilizers are considered to have the greatest potential for use, if required.

The application options, which are considered to have the most potential for use in the application of the required organic substrate into the DCPRB contaminated groundwater, are an injection well system and/or use of the D-Area Interceptor Well, DIW-1, as an injection system. The application option, which is considered to have the most potential for use in the application of the limestone or phosphate rock, if required, is a modified permeable reactive barrier. Commercial fertilizer, if required, could be added as necessary as a solid or liquid through the modified permeable reactive barrier.

It is recommended that phased laboratory and pilot scale testing be conducted to fully address the applicability of sulfate reduction remediation to the DCPRB groundwater plume, and to determine the amendments required to effectively promote such remediation. 
Left Blank Intentionally 


\section{TABLE OF CONTENTS}

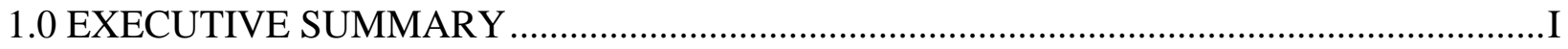

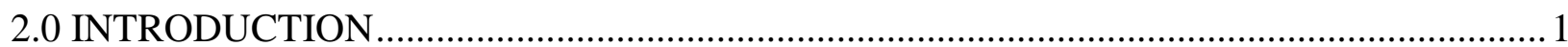

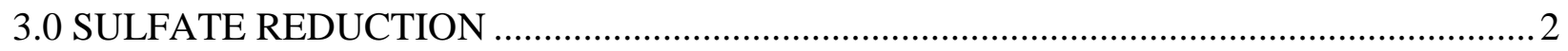

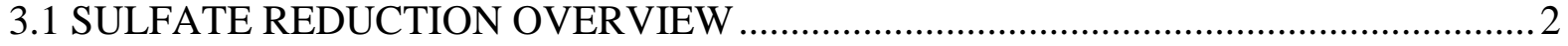

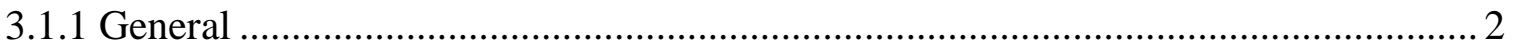

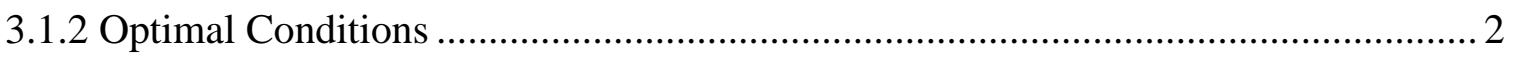

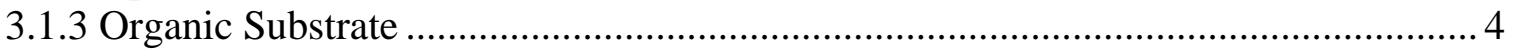

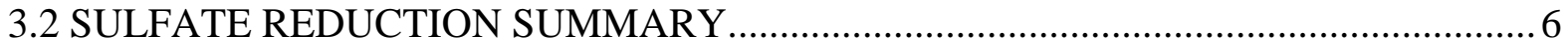

4.0 D-AREA COAL PILE RUNOFF BASIN (DCPRB) GEOCHEMISTRY .......................... 12

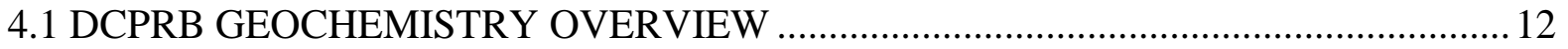

4.2 SULFATE REDUCTION VERSUS DCPRB GEOCHEMISTRY .............................. 14

4.3 POTENTIAL DCPRB SULFATE REDUCTION PRECIPITATES ............................. 16

4.4 POTENTIAL DCPRB GEOCHEMICAL ENHANCEMENTS - BASE, PHOSPHATE, AND NITROGEN AMENDMENT OPTIONS ...................................................... 17

5.0 D-AREA COAL PILE RUNOFF BASIN (DCPRB) HYDROGEOLOGY .......................... 19

6.0 D-AREA COAL PILE RUNOFF BASIN (DCPRB) SULFATE REDUCTION

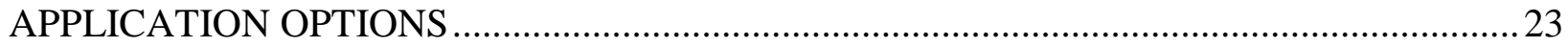

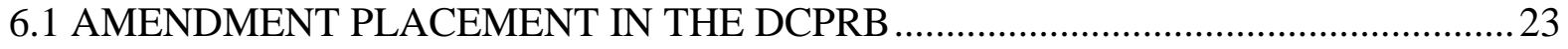

6.2 TRADITIONAL PERMEABLE REACTIVE BARRIER (PRB) ............................... 24

6.3 MODIFIED PERMEABLE REACTIVE BARRIER (PRB) ....................................... 24

6.4 GEOSIPHON/GEOFLOW SYSTEM................................................................ 25

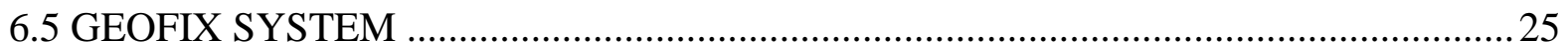

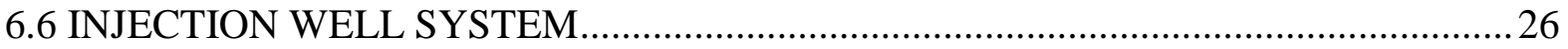

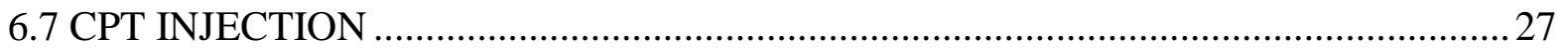

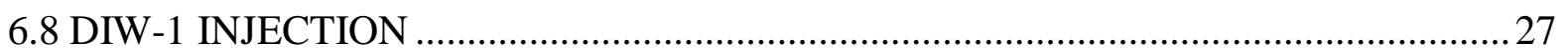

6.9 GROUNDWATER EXTRACTION WITH EX-SITU BIOREACTOR.........................28

6.10 GROUNDWATER EXTRACTION WITH CONSTRUCTED WETLANDS..............28

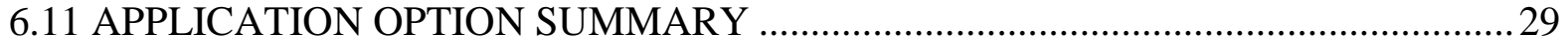

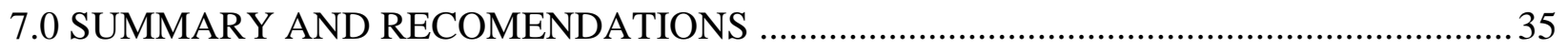

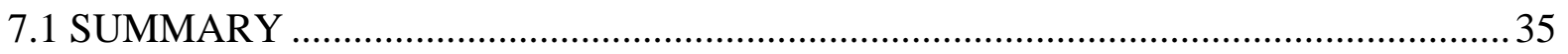

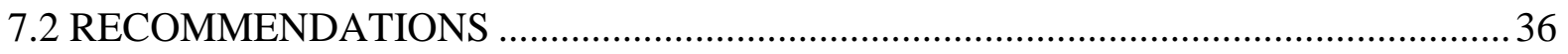

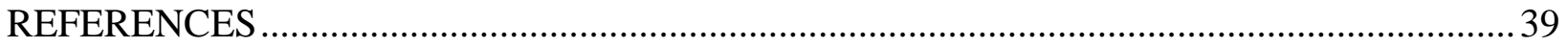




\section{LIST OF TABLES}

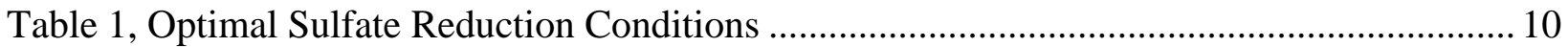

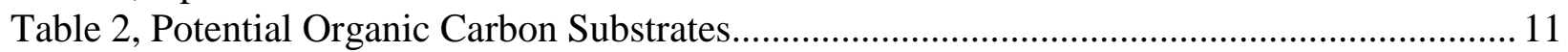

Table 3, DCPRB Groundwater Geochemistry ............................................................... 13

Table 4, DCPRB Groundwater Geochemistry versus Optimal Sulfate Reduction Conditions .... 15

Table 5, Average Dissolved Metal Concentrations and Potential Mineral Precipitates .............. 17

Table 6, Sulfate Reduction Base, Phosphate, and Nitrogen Amendment Options ...................... 18

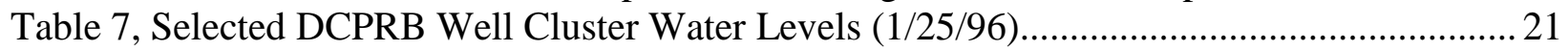

Table 8, Selected DCB-21, DCB-22, and DCB-23 Analytical Results (11/97)......................... 22

Table 9, Sulfate Reduction Application System Options Advantages and Disadvantages........... 31

Table 10, Sulfate Reduction Application System Options Recommendations ........................... 34

\section{LIST OF FIGURES}

Figure 1, Organization and Carbon Flow of a Microbial Community of Fermenters, Sulfate Reducers and Methanogens

Figure 2, Standard Redox Potentials (pH 7) of some Important Redox Couples and Free Energy Changes Involving Two Redox Couples in Respiratory Processes and $\mathrm{H}_{2} / \mathrm{CO}_{2}$ Methanogenesis

Figure 3, D-Area Coal Pile Runoff Basin (DCPRB) Location Map ......................................... 44

Figure 4, Ferrous Monosulfide Solubility.................................................................... 45

Figure 5, Aluminum and Chromium Hydroxide Solubility ............................................. 45

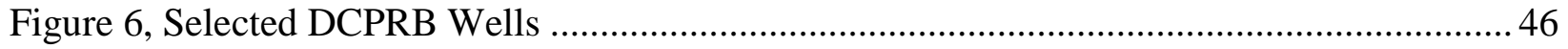

Figure 7, DCPRB Water Table Aquifer Hydraulic Conductivity Profile ................................. 47

Figure 8, Well DCB-25 Ambient and Differential Ambient Groundwater Flow ....................... 47

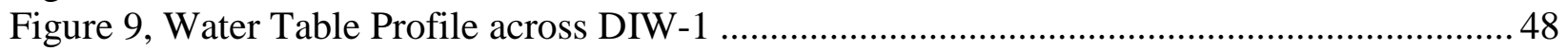

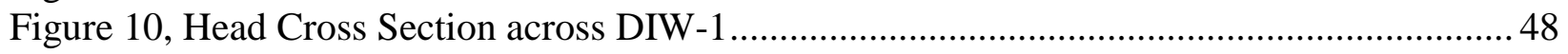




\section{D-AREA COAL PILE RUNOFF BASIN SULFATE REDUCTION LITERATURE REVIEW AND FEASIBILITY REPORT (U)}

\subsection{INTRODUCTION}

The Savannah River Site (SRS) 484-D Powerhouse burns coal to produce electricity and steam for use at SRS. Coal for the powerhouse is stored in a maximum 8.9-acre pile adjacent to it. Chemical and biological oxidation of the sulfur compounds in the coal occurs, which produces sulfuric acid. Rainwater and the sulfuric acid leach other impurities from the coal, producing an acidic runoff with substantial heavy metals and sulfate contamination. The D-Area Coal Pile Runoff Basin (DCPRB) was built in 1978 to receive this runoff from the D-Area coal pile. The basin was designed as a sedimentation/seepage basin for the removal of suspended solids and to minimize the direct discharge of coal pile runoff to Beaver Dam Creek. The basin has a surface area, operating volume, and maximum volume of 12.5 acres, 10 to 13 million gallons (MG), and 14.5 MG, respectively. From the basin this acidic water, containing heavy metals (primarily iron and aluminum) and sulfate, seeps into the shallow water table aquifer. The water table aquifer subsequently discharges into adjacent surface streams, the Savannah River swamp, and possibly the Savannah River itself, which is the site boundary. (Phifer, et al., 1996) Portions of this plume near the source have a pH approaching 2.0 and heavy metal concentrations exceeding Maximum Contaminant Levels (MCLs) established by the National Primary Drinking Water Regulations. Remedial action for the groundwater contaminated by this RCRA/CERCLA unit will be required to mitigate the migration of highly contaminated groundwater towards adjacent surface water bodies. Such remedial action is complicated due to the anticipation that the powerhouse will continue to operate for many more years (until between 2005 and 2015) and will therefore continue to provide a source of contaminated water to the DCPRB until it is shut down.

A previous study (Phifer and Denham, 2000) recommended the following to the Environmental Restoration Division (ERD) concerning remediation of this groundwater plume:

"A Permeable Reactive Barrier (PRB) based upon a Sulfate Reduction geochemical approach is currently considered the most feasible approach for the remediation of the D-Area low $\mathrm{pH}$ groundwater plumes utilizing the PRB technology. The current D-Area low $\mathrm{pH}$ groundwater plume geochemical conditions appear optimal for a Sulfate Reduction PRB. However, Sulfate Reduction PRBs are still considered to be in the research and development stage with limit documented field trials of the technology. For Sulfate Reduction PRB technology to be seriously considered for remediation of the D-Area low $\mathrm{pH}$ groundwater plume, it is recommended that laboratory and actual in situ field-testing be conducted."

This previous study also recommended that ERD reconsider whether or not PRB technology is the most appropriate means to implement sulfate reduction remediation of this groundwater plume (Phifer and Denham, 2000).

Based upon these recommendations ERD requested that a literature review be performed to assess the feasibility of sulfate reduction as a means to remediate this groundwater plume in conjunction with monitored natural attenuation. This report provides the results of this literature review. 


\subsection{SULFATE REDUCTION}

\subsection{SULFATE REDUCTION OVERVIEW}

\subsubsection{General}

When sulfur is assimilated into bacteria and other biological systems, it is often used to produce structural proteins. Microorganisms also couple the oxidation of carbon substrates to the reduction of sulfate for energy production and growth. This process is known as dissimilitory sulfate reduction and is accomplished by sulfate reducing bacteria (SRB). Although SRB are morphologically and phylogenetically diverse, they are viewed as a physiologically unified group (Barton, 1995). In the process of dissimilitory sulfate reduction, sulfate serves the same function as oxygen does for aerobic respiration (i.e. terminal electron acceptor). In either case, when organic carbon substrates are oxidized they provide carbon for growth and a source of electrons for energy production. Energy production during respiration occurs when electrons are transferred to a terminal electron acceptor. During respiration bacteria can use sulfate or oxygen as terminal electron acceptors. However, in general, oxygen respirers cannot use sulfate and sulfate reducers cannot use oxygen as terminal electron acceptors (Fauque, 1995).

SRB play a significant role in the microbial ecology of soils and sediments by removing "waste" products produced by other types of bacteria that degrade more complex organic compounds (see Figure 1). Ultimately, carbon is converted to $\mathrm{CO}_{2}$ and sulfate is converted to $\mathrm{H}_{2} \mathrm{~S}$, both of which are gases and therefore leave the sediment. In addition, $\mathrm{H}_{2} \mathrm{~S}$ can also react with metals in the environment and result in their immobilization via the formation of reduced minerals. Consequently, SRB also play significant roles in the global carbon cycle as well as biogeochemical cycling. The ubiquity of SRB in the environment and their ability to catalyze biogeochemical transformation of minerals has been exploited for use in bioremediation. White et al, (1998) have used a bioreactor incorporating SRB to precipitate soluble metals from contaminated soil. In these studies, a removal efficiency greater than $98 \%$ was recorded for $\mathrm{Cd}, \mathrm{Cr}, \mathrm{Co}, \mathrm{Mn}, \mathrm{Pb}$, and $\mathrm{Zn}$. Initial concentrations for each metal in the soil was $1 \mathrm{mmol} / \mathrm{kg}$ dry soil. In-situ reduction and immobilization of metals has also been accomplished with stimulation of SRB. The addition of organic substrates in conjunction with $\mathrm{pH}$ abatement has been shown to effectively decrease metal concentrations in groundwater.

\subsubsection{Optimal Conditions}

SRB are widespread in the environment and are detected in highest numbers from environments that are most conducive to their growth and survival. SRB grow best in a $\mathrm{pH}$ range from 5.5 - 9.0 (Fauque, 1995). However sulfate reduction has been recorded from acid mine drainage and a fresh water peat bog with $\mathrm{pH}$ values as low as 2.5 . This may be due to the formation of biofilms of SRB around geologic substrates that provide a more alkaline microenvironment and therefore allow sulfate reduction to occur under otherwise harsh conditions. The $\mathrm{pH}$ ultimately increased in studies in which SRB growth was promoted under acidic conditions. Tuttle et al (1969) demonstrated a $\mathrm{pH}$ increase from 4 to 7 in 10 
days of incubation with wood chips and $0.1 \%$ lactate at $37^{\circ} \mathrm{C}$. During this time Eh values fell from $300 \mathrm{mV}$ to $-250 \mathrm{mV}$ along with approximately $700 \mathrm{ppm}$ of sulfate removed from the system. SRB grow best in an Eh range from 0 to $-150 \mathrm{mV}$ (see Figure 2) (Fenchel, et al., 1998 and Thomas, et al., 1999).

Sufficient organic carbon substrate to supply carbon and energy is necessary for optimal SRB growth (see section 3.1.3 for further discussion).

Other nutritional requirements of SRB are the need for nitrogen and phosphorous. These elements are important in cellular growth and energy production. The amounts needed depend on the bacterial density at a given site and their physiological state (i.e. growing or just maintaining activity). Assuming growth conditions are being met, if 1 gram of sediment contains $10^{8}$ bacteria, approximately $0.02 \mathrm{mM}$ of phosphorous per kilogram of soil is required for the population to double. Phosphorous is often assimilated as $\mathrm{PO}_{4}{ }^{-3}$. Nitrogen requirements are usually 5 times that of phosphorous, so for $10^{8}$ cells/kilogram of soil, about $0.1 \mathrm{mM}$ of nitrogen per kilogram of soil is required for the population to double.

Supplemental nitrogen is usually in the form of $\mathrm{NH}_{4}{ }^{+}$, but can also be in the form of $\mathrm{NO}_{3}{ }^{-}$. Overall, the ratio of C:N:P is generally considered to be 100:5:1. So if $670 \mathrm{mM}$ of lactate can result in the reduction of $1 \mathrm{M}$ of $\mathrm{SO}_{4}{ }^{-2}$ over a length of time, the cumulative amounts of $\mathrm{N}$ and $\mathrm{P}$ required are 33.5 and $6.7 \mathrm{mM}$, respectively. In an aquifer where groundwater is continuously moving past the sediment, a continuous influx of nitrogen and phosphorous sources is likely.

Competition for carbon and energy sources is also a part of the ecology of SRB. SRB compete for carbon substrates and micronutrients with both aerobic bacteria and other anaerobic bacteria that can utilize terminal electron acceptors other than sulfate. The major anaerobic competitors use the following as terminal electron acceptors; $\mathrm{NO}_{3}{ }^{-}$(nitrate reducers), $\mathrm{Mn}(\mathrm{IV})$ (manganese reducers), $\mathrm{Fe}$ (III) (iron reducers) and $\mathrm{CO}_{2}$ (methanogens). The thermodynamic favorability of these compounds and the redox conditions that favor these specific reactions is listed in Figure 2. As shown in Figure 2 thermodynamic favorability for each class of bacteria proceeds in the following order: aerobic bacteria $\left(\mathrm{O}_{2} \rightarrow\right.$ $\left.\mathrm{H}_{2} \mathrm{O}\right)$, nitrate reducers $\left(\mathrm{NO}_{3}{ }^{-} \rightarrow \mathrm{NO}_{2}{ }^{-} \rightarrow \mathrm{N}_{2} \mathrm{O} \rightarrow \mathrm{N}_{2}\right)$, manganese reducers $\left(\mathrm{MnO}_{2} \rightarrow\right.$ $\left.\mathrm{MnCO}_{3}\right)$, iron reducers $\left(\mathrm{FeOOH} \rightarrow \mathrm{FeCO}_{3}\right)$, sulfate reducers $\left(\mathrm{SO}_{4}{ }^{-2} \rightarrow \mathrm{HS}^{-}\right)$, and methanogens $\left(\mathrm{CO}_{2} \rightarrow \mathrm{CH}_{4}\right)$. While thermodynamics play a part in determining which organisms out-compete for carbon substrates, other factors also must be considered. Some SRB have been shown to assimilate nitrate as a building block for protein production and thereby decrease the available nitrate for competing anaerobes. In addition the concentration of terminal electron acceptors also plays a significant part. Oxygen is not only a terminal electron acceptor for competing aerobic bacteria, but it is toxic to many SRB even though they have been reported to tolerate small quantities of oxygen (Fauque, 1995). When sulfate concentrations are high, SRB are expected to predominate. Another competitive advantage of SRB is the toxic nature of their end product, $\mathrm{H}_{2} \mathrm{~S}$, to other bacteria. In addition, $\mathrm{H}_{2} \mathrm{~S}$ is a highly reductive compound, which has the potential of reducing terminal electron acceptors and thereby rendering them thermodynamically useless for competing microbes. 


\subsubsection{Organic Substrate}

Organic carbon substrates such as wood dust, wood chips, leaf mulch, etc. have all demonstrated some utility as a source of carbon for sulfate reducers. While they all have potential in passive systems, it is important to consider their rate and degree of biodegradation in-situ. These carbon substrates will be degraded anaerobically if used in permeable reactive barrier (PRB) configuration (Chynoweth, et al. 1993; Schank, et al. 1993 and Turick et al. 1991). Anaerobic degradation is well suited for the delivery of simple carbon substrates to SRB over extended periods of time. However not all carbon substrates are degraded at the same rate. Degradation rates often depend on the specific type of biomass. In addition, not all the biomass will be degraded in an anaerobic system. For instance, the lignocellulosic component of biomass is very resistant to anaerobic degradation. Consequently, this portion (sometimes $\geq 50 \%$ ) of the biomass will either remain in-situ or have to be removed. In addition, the rates of degradation can be multiphasic, based on the particular biomass used. Various hardwoods demonstrate biphasic degradation rates, presumably due to their structural composition (Turick et al 1993) while conifers are degraded very slowly (Chynoweth et al. 1993). Since SRB are expected to get their carbon from the breakdown of these carbon substrates, the rate(s) and degree of biomass degradation will control carbon flow to SRB. Fluctuations or overestimated rates in carbon flow to SRB will impact their activity and the reliability of the passive system.

Studies have been conducted on the in situ, passive treatment of acid mine drainage (low $\mathrm{pH}$ and heavy metals) utilizing permeable reactive barriers (PRB), containing solid organic substrates. These studies relied on the natural flow of contaminated groundwater through the PRB. One of the advantages of this strategy is that the organic substrates do not have to be added on a continual basis. Ideally, the organic carbon substrate is degraded slowly thereby releasing carbon at low concentrations over an extended time period. Possible organic substrates for use in these systems include wood dust, wood bark, leaves, sewage, wastepaper, algae, aquatic weeds and waste vegetable material (Tuttle, et al. 1969). Some of the initial studies in this area used $100 \mathrm{~g}$ of untreated wood dust (oak) /liter of acid mine water. These studies demonstrated a $\mathrm{pH}$ increase from $3.6-4.2$ and $10.0 \mathrm{mg} / \mathrm{l}$ of sulfate removal per day after 14 days incubation at $22^{\circ} \mathrm{C}$ (Tuttle, et al. 1969). When partially decomposed wood dust was used the sulfate removal rate nearly doubled that of untreated wood dust. This was likely due to the increase of carbon substrates available for SRB from the sequential breakdown of the wood by a consortia of anaerobic bacteria. This complex microbial ecology provides low molecular weight carbon substrates for SRB from the waste products of bacteria that degrade the higher molecular weight organics (see Figure 1). Consequently, the activity and efficiency of SRB is dependent on the degradative ability of other microbes.

In a similar study, Waybrant et al (1998) evaluated various organic compounds for the treatment of acid mine drainage. This study incorporated biomass carbon substrates for use in reactive permeable walls. The carbon substrates included composted sewage sludge, composted sheep manure, wood chips, sawdust, leaf mulch and cellulose. Leaf mulch (27 Wt \% organic carbon) and cellulose (19 Wt \% organic carbon) increased sulfate reduction 
and remained available as carbon substrates for over 60 days. The sulfate reduction rates were influenced the least by sheep manure and sewage sludge.

The influence of carbon substrates on SRB activity in mixed microbial communities is not straightforward. For instance, the addition of $0.1 \%$ glucose to wood dusts increased SRB activity by 8.3 percent when added to acid mine waters. However the addition of $1.0 \%$ glucose actually decreased SRB activity relative to untreated wood dust. (Tuttle et al, 1969). This may have been due to an increase in the populations of non-SRB that out competed SRB for this readily available carbon source. Similarly, the minimal affect on sulfate reduction by sewage sludge and sheep manure (Waybrant et al, 1998) may have also been a result of SRB being out competed for the a high concentration of readily available carbon. In these situations, the rapid growth and increase in the numbers of non-SRB contribute to an "unbalanced" condition. Consequently, it is important to choose the proper carbon substrates at the right concentration ranges that will favor the growth of SRB and stimulate in-situ sulfate reduction. The additional objective in regards to construction of a passive biotreatment barrier is the gradual release of carbon substrates over time to stimulate and maintain active fermenter and SRB populations.

Lactate and pyruvate are almost universally used as a carbon source and electron donor by SRB (Fauque, 1995. and Ehrlich, 1996). Lactate is ideal for increasing SRB activity. However the solubility of lactate is high and therefore the availability of lactate would also be high, requiring frequent additions to the contaminated site. With the oxidation of lactate coupled to the reduction of sulfate, the $\mathrm{pH}$ of a system can be increased in two ways. Sulfate is reduced to sulfide, the sulfide combines with hydrogen ions to form $\mathrm{H}_{2} \mathrm{~S}$ and increase the $\mathrm{pH}$, and the subsequent gaseous $\mathrm{H}_{2} \mathrm{~S}$ is removed from the environment. When SRB oxidize lactate the resulting $\mathrm{HCO}_{3}{ }^{-}$serves to buffer the system (i.e. $\mathrm{HCO}_{3}{ }^{-}$can combine with additional hydrogen ions to form $\mathrm{H}_{2} \mathrm{CO}_{3}$ ). This process can be expressed in simplified form as follows:

$$
2 \mathrm{CH}_{3} \mathrm{CHOHCOO}^{-}+3 \mathrm{SO}_{4}{ }^{2-}+2 \mathrm{H}^{+} \rightarrow 6 \mathrm{HCO}_{3}{ }^{-}+3 \mathrm{H}_{2} \mathrm{~S} \text { (Benner et al. 1999). }
$$

Furrer et al. (1996) conducted soil column studies over a period of 91 days and determined that after the addition of $3.6 \mathrm{mM}$ of lactate into a soil column, $1.1 \mathrm{mM}$ of carbonate resulted from lactate oxidation. The remaining carbon was in the form of proprionate $(0.8 \mathrm{mM})$ and acetate $(1.5 \mathrm{mM})$. Presumably if this study were carried out longer than 91 days or if initial lactate concentrations were lower some SRB would have oxidized the remaining acetate and proprionate. In addition to carbonate formation, the resulting $\mathrm{H}_{2} \mathrm{~S}$ played a significant role in metal immobilization through the formation of sulfide minerals (Furrer et al. 1996; von Guten and Furrer, 2000).

Lactate can be broken down to acetate, another carbon substrate for some, but not all SRB. Since acetate is volatile, its evolution from lactate in the groundwater circumvents problems associated with its direct addition to the subsurface.

Another carbon substrate often used during active remediation is molasses. This is a very inexpensive and easily obtained carbon substrate consisting primarily of sucrose (Leeper, et 
al. 1991). The high solubility and rapid degradation of molasses may actually minimize SRB activity because the SRB could be out competed for carbon by the rapid increase of other subsurface bacteria. Some evidence for this was presented above with wood dust and glucose. Along with a complex microbial community to breakdown organics to more simple forms for SRB, the proper proportion of the population is also required. Otherwise, the SRB will be out competed for carbon. A rapid influx of easily degraded carbon such as molasses may shift the balance away from SRB.

Vegetable oil has been used in the bioremediation industry as a slow release carbon source and based on results to date is viewed favorably. Vegetable oil can provide a significant amount of carbon to SRB as a result of its breakdown by fermentative bacteria (Chynoweth et al. 1993). The low degree of solubility and low mobility in the subsurface also makes vegetable oil a potentially suitable carbon substrate for passive remediation incorporating SRB. Vegetable oil is degraded slowly because of its low water solubility. Because vegetable oil is a liquid and lighter than water it can be injected into the aquifer as opposed to added by way of excavation, as is the case for solid carbon substrates such as woody biomass and other plant matter. Because of the more homogeneous nature of vegetable oil, fluctuations in degradation rates are expected to be minimal, compared to biomass solids. The difference between slowly degraded liquids like vegetable oil and biomass solids (like leaf litter and wood chips) is related to chemical complexity and bioavailability. The complex lignocellulosic structure of leaves and woods act to decrease the rate of breakdown of these carbon substrates. The rate of carbon influx from biomass solids can vary because some carbon compounds are bound more tightly than others are and therefore are degraded at different rates.

A commercial source of lactate that is marketed as a slow "Hydrogen Release Compound (HRC)" by Regenesis (www.regenesis.com) offers some promise as a long-term source of lactate in a passive system. However there is no data about the performance of this compound in acidic systems. HRC is lactate in a slow release polymeric matrix that has potential to serve as a carbon substrate to SRB. Since it is released slowly with time, it may prove to be suitable for specifically targeting SRB.

In addition, SRB have also been shown to use malate, formate, fatty acids and some alcohols for growth and energy production (Fauque, 1995 and Ehrlich, 1996). Hydrogen is also used by some SRB as an energy source (Fauque, 1995 and Ehrlich, 1996). These various carbon and/or energy sources are obtained from the environment as breakdown products from other types of bacteria. For instance complex organic compounds can be degraded to short chain fatty acids by other bacteria and then utilized by SRB (see Figure 1).

\subsection{SULFATE REDUCTION SUMMARY}

In summary, SRB grow best and are most numerous at pHs of from 5.5-9.0; at Ehs of from 0 to - $150 \mathrm{mV}$; with sufficient available organic carbon substrates that supply carbon and energy; with sufficient nitrogen and phosphate $(\mathrm{C}: \mathrm{N}: \mathrm{P}$ ratio of $100: 5: 1)$; under anaerobic conditions; with minimal nitrate, manganese (IV), ferric iron; and with an abundance of sulfate (see Table 
1). These favorable conditions are evaluated against the current DCPRB conditions in Section 4.2.

Table 2 provides a summary of the advantages and disadvantages of potential SRB organic carbon substrates. The carbon substrates listed in Table 2 are ones that have been most widely utilized for either SRB or trichloroethylene (TCE) remediation. Application methods for these carbon substrates are discussed in Section 6.0. The following are the primary considerations in choosing a carbon substrate(s) to promote sulfate reduction:

1) Direct or indirect SRB carbon substrate

2) Solubility, volatility, and other related properties of the SRB carbon substrate

3) Commercial availability and cost

4) Carbon substrate form (i.e. solid, liquid or solution, or gas which is related to the application method, see section 6.0)

A direct SRB carbon substrate is one that is immediately available for use by SRB, and an indirect SRB carbon substrate is a complex organic carbon that requires other bacteria to break it down before it is available for use by SRB. As outlined in Table 2 lactate, acetate, and Regenesis HRC (contains lactate) are direct SRB carbon substrates. Lactate is regarded as a universal direct carbon substrate for SRB, whereas acetate is a direct SRB carbon substrate only for some SRBs. However acetate is a potential microbial breakdown product of lactate. The typical advantage of direct SRB carbon substrate is that they are immediately available for use by SRB. Therefore the desired reactions start up relatively quickly, and the kinetics is relatively fast as long as the carbon substrate lasts. However, a disadvantage of direct SRB carbon substrates is that since they are utilized relatively rapidly, they require relatively frequent reapplications. Also as outlined in Table 2 wood chips/leaf mulch/compost, molasses (sucrose) and soy or vegetable oil, are indirect carbon substrates. Indirect SRB carbon substrates have the opposite advantages and disadvantages to those of direct carbon substrates. Indirect SRB carbon substrates, which require other bacteria (such as fermenting bacteria) to break it down before it is available for use by SRB, have the potential disadvantages of a relatively slow SRB reaction start up and of relatively slow SRB, long-term kinetics, due to the limited availability of actual SRB carbon substrates. However, a typical advantage of indirect SRB carbon substrates is that they provide a long-term, gradual release of carbon for use by SRB and therefore require less frequent re-applications than a direct SRB carbon substrate. Although Regenesis HRC is a direct SRB carbon substrate, it has been formulated to try and have the advantages of both direct and indirect SRB carbon substrates without the disadvantages. HRC is a polylactate ester formulated for slow release of lactate upon hydration. As such it purports to be a direct substrate of lactate released at a controlled rate. Therefore it may provide for both relatively quick reaction start up and relatively fast kinetics along with being a long-term, gradual release source of lactate. Therefore it may require less frequent re-applications than other direct SRB carbon substrates.

Lactate, acetate, and molasses are very soluble and can therefore be degraded very quickly. This produces a spike of available carbon with each application followed by a fairly rapid decrease in concentrations requiring frequent re-applications. Acetate concentration may decrease even more rapidly than the other organics, since it is volatile and significant amounts could be lost to the atmosphere. Additionally since they are very soluble care must be exercised in order to 
ensure that excessive carbon substrate concentrations are not produced that could led to the out competition of SRB by other microbes. While this can be somewhat of a problem with soluble, direct SRB carbon substrates, it is more of a problem with soluble, indirect SRB carbon substrates such as molasses, which are preferentially utilized by non-SRB microbes. In high concentrations this can easily lead to out competition of SRB by other microbes. To overcome this problem associated with soluble indirect carbon substrates such as molasses a continual addition of dilute solutions could be applied, however this could be a relatively expensive solution. Wood chips/leaf mulch/compost, soy or vegetable oil, and HRC are considered to be either insoluble or to have a low solubility. They depend upon breakdown by other microorganisms to produce soluble, direct SRB carbon substrates for use by the SRBs. For this reason, as stated previously, they provide a long-term, gradual release of carbon for use by SRB, and therefore require less frequent re-applications than more soluble carbon substrates.

Wood chips/leaf mulch/compost, molasses, and soy or vegetable oils are all commercially available and relatively inexpensive. Whereas lactate, acetate, and $\mathrm{HRC}$, while commercially available, are relatively expensive, with HRC being the most expensive. Lactate and acetate waste products may be commercially available at a lower cost than the commercial product, however such waste products could contain metal impurities.

Wood chips/leaf mulch/compost are solids and as such are difficult to re-apply in-situ. As further discussed in Section 6.2, since the D-Area Coal Pile Runoff Basin (DCPRB) will continue to operate for the foreseeable future, the mass of organic solids required can not be determined and re-application will be required if such solids are utilized. Re-application of organic solids will cost essentially the same as the initial application. This is not necessary the case with the use of organic solutions or liquids, depending upon the application method utilized. Organic solutions or liquids should be relatively easy to re-apply. Additional discussion concerning application methods are provided in section 6.0. Organic solutions will quickly disperse into the groundwater and move with the groundwater, whereas the organic liquids will display different properties. Soy or vegetable oil has a specific gravity less than water, a low solubility, and disperses slowly. As such soy or vegetable oil will float and provide a long-term carbon substrate, which should essentially stay where placed. HRC has a specific gravity greater than water, a low solubility, and should disperse slowly. As such HRC will sink and provide a long-term carbon substrate, which should essentially stay where placed.

Based upon the above discussion, the use of acetate is not recommended for the following reasons:

- It is only a direct SRB carbon substrate for some SRBs, whereas lactate is a universal direct SRB carbon substrate.

- It is volatile, and significant amounts could be lost to the atmosphere.

Additionally based upon the above discussion, the use of molasses is not recommended for the following reasons:

- Non-SRB microbes preferentially utilize molasses, and in high concentrations this can easily lead to out competition of SRB by other microbes. 
- The continual addition of a dilute molasses solution to potentially overcome out competition is relatively expensive.

Also based upon the above discussion, the use of solid organics such as wood chips/leaf mulch/compost is not recommended, since the mass of organic solids required, can not be determined and the required re-application will essentially duplicate the initial application, including its cost.

The carbon substrates, which are considered to have the greatest potential to promote SRB growth and subsequent sulfate reduction at the DCPRB, include lactate, soy or vegetable oil, and HRC for the following reasons:

- Lactate is a universal, direct, soluble carbon substrate for SRB and will allow for relatively fast start up of the system and relatively fast kinetics.

- Soy or vegetable oil should provide a floating, stationary, long-term, gradual release SRB carbon substrate, should require less frequent re-applications, and is relatively inexpensive.

- HRC should allow for relatively fast start up of the system and relatively fast kinetics, should provide a stationary, long-term, gradual release SRB carbon substrate on top of a clay layer below the water table, and should require less frequent re-applications.

The various properties of lactate, soy or vegetable oil, and HRC may make either their use alone or in combination beneficial. For instance, lactate may be added one time at the beginning of a project in order to increase SRB numbers. This way another carbon substrate, such as vegetable oil, could be used to degrade slowly and provide carbon to the previously enhanced SRB population. Physical characteristics also make the tandem addition of carbon substrates appealing. For instance, the highest contaminant concentration and lowest $\mathrm{pH}$ is closest to the water table in D Area. The addition of vegetable oil will likely result in sulfate reduction, although the rates may be deterred by the $\mathrm{pH}$. Since vegetable oil is less dense than water, it will be concentrated in the most contaminated area, where growth will be slow due to the low $\mathrm{pH}$. However, HRC is heavier than water and is expected to sink to the less contaminated portion of the aquifer. By stimulating SRB in this region, sulfate reduction and the accompanying increase in $\mathrm{pH}$ will proceed from the bottom up. Under this scenario, SRB will be provided carbon from two different directions. As the sulfate is reduced from the lowest to the highest concentrations, the resulting increase in $\mathrm{pH}$ will provide a more suitable growth environment for the SRB in the area of higher contamination. 
Table 1

Optimal Sulfate Reduction Conditions

\begin{tabular}{|c|c|c|}
\hline Parameter & $\begin{array}{l}\text { Optimal SRB Conditions } \\
\text { Relative to the Parameter }\end{array}$ & Comments \\
\hline $\mathrm{pH}$ & 5.5 to 9.0 & - \\
\hline Eh & 0 to $-150 \mathrm{mV}$ & - \\
\hline Organic Carbon & $0.5-3 \mathrm{M}$ & SRB substrate and electron donor \\
\hline $\begin{array}{c}\text { Nitrogen } \\
\left(\mathrm{NH}_{4}^{+} \text {or } \mathrm{NO}_{3}^{-}\right)\end{array}$ & $\begin{array}{l}\mathrm{mg} / \mathrm{L} \text { range of soluble organic or } \\
\text { inorganic nitrogen }\end{array}$ & SRB micro- nutrient \\
\hline $\begin{array}{l}\text { Phosphate } \\
\left(\mathrm{PO}_{4}^{-3}\right)\end{array}$ & $\begin{array}{l}\mathrm{mg} / \mathrm{L} \text { range of soluble organic or } \\
\text { inorganic phosphate }\end{array}$ & SRB micronutrient \\
\hline $\begin{array}{l}\text { Dissolved Oxygen } \\
\qquad\left(\mathrm{O}_{2}\right)\end{array}$ & 0 -trace & $\begin{array}{l}\text { Aerobic microbe competition; } \\
\text { toxic to many SRB }\end{array}$ \\
\hline $\begin{array}{l}\text { Nitrate } \\
\left(\mathrm{NO}_{3}^{-}\right)\end{array}$ & Small fraction of $\mathrm{SO}_{4}$ concentration & Nitrate reducer competition \\
\hline $\begin{array}{l}\text { Manganese } \\
\left(\mathrm{Mn}^{+4}\right)\end{array}$ & Small fraction of $\mathrm{SO}_{4}$ concentration & Manganese reducer competition \\
\hline $\begin{array}{l}\text { Ferric Iron } \\
\quad\left(\mathrm{Fe}^{+3}\right)\end{array}$ & Small fraction of $\mathrm{SO}_{4}$ concentration & Iron reducer competition \\
\hline $\begin{array}{l}\text { Sulfate } \\
\left(\mathrm{SO}_{4}{ }^{-2}\right)\end{array}$ & 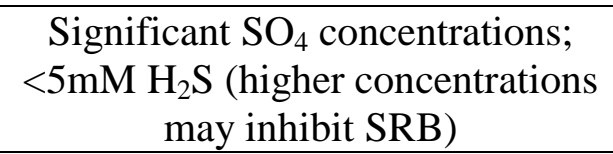 & SRB Electron acceptor \\
\hline $\begin{array}{l}\text { Acetate } \\
\mathrm{H}_{2} / \mathrm{CO}_{2}\end{array}$ & $\begin{array}{l}\mathrm{Eh}>-150 \mathrm{mV} \\
\text { presence of sulfate }\end{array}$ & $\begin{array}{l}\text { Methanogen competition for } \\
\text { carbon or hydrogen }\end{array}$ \\
\hline
\end{tabular}

Sources: Benner et al., 1999; Chapelle, 1993; EPA, 1999a; Fauque, 1995; Fenchel et al., 1998; Thomas et al., 1999 
Table 2

Potential SRB Organic Carbon Substrates

\begin{tabular}{|c|c|c|c|}
\hline Organic Carbon & Form & Advantages & Disadvantages \\
\hline $\begin{array}{l}\text { Wood chips/leaf } \\
\text { mulch/compost }\end{array}$ & Solid & $\begin{array}{cc}\text { - } & \text { Indirect SRB carbon substrate: } \\
\text { - } & \text { Gradual release of SRB carbon } \\
\text { substrates } \\
\text { - } & \text { Requires less frequent re-application } \\
\text { - } & \text { Insoluble but some breakdown products } \\
& \text { are soluble } \\
& \text { Non-volatile } \\
- & \text { Locally available } \\
& \text { - } \\
& \text { Inexpensive }\end{array}$ & $\begin{array}{cc}\text { - } & \text { Indirect SRB carbon substrate: } \\
\text { - } & \text { Potentially slow kinetics } \\
\text { - } & \text { Potentially slow start up } \\
\text { - } & \text { Difficult to re-apply }\end{array}$ \\
\hline Lactate & Solution & $\begin{array}{cc}\text { - } & \text { Direct SRB carbon substrate: } \\
\text { - } & \text { Relatively fast kinetics } \\
\text { - } & \text { Relatively fast start up } \\
& -\quad \text { Soluble } \\
& -\quad \text { Non-volatile } \\
- & \text { Commercially available }\end{array}$ & $\begin{array}{cc}\text { - } & \text { Direct SRB carbon substrate: } \\
\text { - } & \text { Requires frequent re-application } \\
\text { - } & \text { Commercial product could be expensive } \\
\text { - } & \text { Waste produce could contain metal } \\
\text { impurities }\end{array}$ \\
\hline Acetate & Solution & $\begin{array}{cc}\text { - } & \text { Direct SRB carbon substrate for some } \\
& \text { SRBs: } \\
\text { - } & \text { Relatively fast kinetics } \\
\text { - } & \text { Relatively fast start up } \\
& -\quad \text { Soluble } \\
\text { - } & \text { Commercially available } \\
\text { - } & \text { Potential lactate breakdown product }\end{array}$ & $\begin{array}{c}\text { - Direct SRB carbon substrate: } \\
\text { - } \quad \text { Requires frequent re-application } \\
\text { - } \quad \text { Commercial product could be expensive } \\
\text { Waste produce could contain metal } \\
\text { impurities } \\
\text { - } \quad \text { Volatile (may be lost to atmosphere) }\end{array}$ \\
\hline $\begin{array}{l}\text { Molasses } \\
\text { (Sucrose) }\end{array}$ & Solution & $\begin{array}{cc}\text { - } & \text { Indirect SRB carbon substrate: } \\
\text { - } & \text { Gradual release of SRB carbon } \\
\text { substrates } \\
\text { - } \quad \text { Requires less frequent re-application } \\
-\quad \text { Soluble } \\
-\quad \text { Non-volatile } \\
-\quad \text { Commercially available } \\
-\quad \text { Inexpensive }\end{array}$ & $\begin{array}{c}\text { - Indirect SRB carbon substrate: } \\
\text { - Potentially slow kinetics } \\
\text { - } \quad \text { Potentially slow start up } \\
\text { High concentrations could cause SRBs } \\
\text { to be out competed by other microbes } \\
\text { - } \\
\text { Requires a continual addition of dilute } \\
\text { solution }\end{array}$ \\
\hline $\begin{array}{c}\text { Soy oil or } \\
\text { vegetable oil }\end{array}$ & Liquid & $\begin{array}{cc}\text { - } & \text { Indirect SRB carbon substrate } \\
\text { - } & \text { Gradual release of SRB carbon } \\
\text { substrates } \\
\text { - } \quad \text { Requires less frequent re-application } \\
\text { Low solubility and slow dispersion, but } \\
\text { some breakdown products are soluble } \\
\text { - Non-volatile } \\
\text { - } \quad \text { Lower specific gravity than water (i.e. } \\
\text { floats) } \\
\text { Commercially available } \\
-\quad \text { Inexpensive }\end{array}$ & $\begin{array}{cc}\text { - } & \text { Indirect SRB carbon substrate: } \\
\text { - } & \text { Potentially slow kinetics } \\
\text { - } & \text { Potentially slow start up }\end{array}$ \\
\hline $\begin{array}{l}\text { Regenesis HRC } \\
\text { (hydrogen } \\
\text { release } \\
\text { compound) }\end{array}$ & Liquid & $\begin{array}{ccc}- & \text { Direct SRB carbon substrate (lactate) } \\
& -\quad \text { Somewhat fast kinetics } \\
& -\quad \text { Somewhat fast start up } \\
- & \text { Gradual release of lactate } \\
- & \text { Requires less frequent re-application } \\
& \text { HRC low solubility and possibly slow } \\
& \text { dispersion } \\
- & \text { Lactate soluble } \\
-\quad \text { Greater specific gravity than water (i.e. } & \text { sinks) } \\
& \text { Commercially available }\end{array}$ & $\begin{array}{c}-\quad \text { Expensive } \\
-\quad \text { MSDS cautions about adding to acidic } \\
\text { media }\end{array}$ \\
\hline
\end{tabular}




\subsection{D-AREA COAL PILE RUNOFF BASIN (DCPRB) GEOCHEMISTRY}

\subsection{DCPRB GEOCHEMISTRY OVERVIEW}

Shallow groundwater at the far northwestern (SRS grid) end of the DCPRB is among the highest contaminated groundwater emanating from the DCPRB. Groundwater contamination levels decrease significantly to the south along the berm of the basin and also decrease with depth. The D-Area Interceptor Well, DIW-1, is located in this area of greatest groundwater contamination (see Figure 3). Monitoring well DCB-49 is located adjacent to the DCPRB berm south of DIW-1 (see Figure 3). Table 3 provides groundwater data from monitoring wells in the vicinity of DIW1 (high contamination area) and from monitoring well DCB-49 (moderate contamination area). Groundwater data collected both before and after DIW-1 was installed indicate that the groundwater near DIW-1 is very acidic and predominately contaminated with iron, aluminum, and sulfate. Other metals found in lesser concentrations include cadmium, chromium, cobalt, copper, lead, manganese, nickel, and zinc (see Table 3). The contaminants from well DCB-49 are similar to those near DIW-1, but the $\mathrm{pH}$ is higher and the metals concentrations are lower. 
Table 3

DCPRB Groundwater Geochemistry

\begin{tabular}{|c|c|c|c|c|}
\hline \multirow[t]{2}{*}{ Parameter $^{1}$} & \multicolumn{3}{|c|}{ Geochemistry in the Vicinity of DIW-1 ${ }^{2}$} & \multirow{2}{*}{$\begin{array}{c}\text { DCB-49 } \\
\text { Geochemistry }\end{array}$} \\
\hline & Minimum & Maximum & Average & \\
\hline Aluminum $(\mathrm{mg} / \mathrm{L})$ & 8.22 & 1353.80 & 560.15 & 8.77 \\
\hline Cadmium (mg/L) & $<0.002$ & 1.570 & 0.306 & NA \\
\hline Chromium (mg/L) & $<0.040$ & 1.260 & 0.428 & $<0.1$ \\
\hline Cobalt $(\mathrm{mg} / \mathrm{L})$ & 0.565 & 1.960 & 1.124 & NA \\
\hline Copper $(\mathrm{mg} / \mathrm{L})$ & 0.165 & 1.780 & 0.599 & NA \\
\hline Iron $(\mathrm{mg} / \mathrm{L})$ & 1.23 & 9236.60 & 2135.85 & 33.40 \\
\hline $\mathrm{Fe}(\mathrm{II}) / \mathrm{Fe}($ total $)$ & NA & NA & NA & 0.976 \\
\hline Lead $(\mathrm{mg} / \mathrm{L})$ & $<0.002$ & 0.310 & 0.039 & NA \\
\hline Manganese (mg/L) & 0.480 & 336 & 38.702 & 0.601 \\
\hline Nickel (mg/L) & $<0.050$ & 14.44 & 4.712 & 0.156 \\
\hline Zinc $(\mathrm{mg} / \mathrm{L})$ & 0.06 & 28.33 & 8.96 & NA \\
\hline $\mathrm{pH}$ & 1.55 & 3.88 & 2.46 & 4.12 \\
\hline Eh $(\mathrm{mV})$ & 506 & 817 & 628 & 461.5 \\
\hline Total Organic Carbon $(\mathrm{mg} / \mathrm{L})$ & 2 & 34.6 & 6.3 & NA \\
\hline Total $\mathrm{PO}_{4}$ as $\mathrm{P}(\mathrm{mg} / \mathrm{L})$ & 0.02 & 0.48 & 0.14 & NA \\
\hline Phosphorus (mg/L) & NA & NA & NA & $<0.64$ \\
\hline Dissolved $\mathrm{O}_{2}(\mathrm{mg} / \mathrm{L})$ & 0.4 & 3.2 & 0.81 & 4.6 \\
\hline Nitrate as $N(\mathrm{mg} / \mathrm{L})$ & $<0.05$ & 3.28 & 0.53 & 6.9 \\
\hline Sulfate $(\mathrm{mg} / \mathrm{L})$ & 326 & 33400 & 7877 & 410 \\
\hline Dissolved $\mathrm{CO}_{2}(\mathrm{mg} / \mathrm{L})$ & NA & NA & NA & $278.89^{4}$ \\
\hline Dissolved $\mathrm{H}_{2}(\mathrm{mg} / \mathrm{L})$ & NA & NA & NA & $2.07 \mathrm{E}-6^{4}$ \\
\hline
\end{tabular}

NA $=$ not analyzed

${ }^{1}$ Metal values are dissolved metal concentrations.

${ }^{2}$ Groundwater data come from wells DCB-1A, 10, 18A, 18B, 19A, 19B, 21A, 21B, 22A, and 22B (1984-1997); for wells DCB-1A, 18A, 18B, 22A, and 22B data were collected before the D-Area Interceptor Well (DIW-1) was installed (Sources: GIMS database and unpublished data collected for the D-Area MagSep project).

${ }^{3}$ Source: Washburn, et al., 1999

4 One-time sample from DCB-49 using Microseeps Bubble Strip Method (Source: Washburn, et al., 1999). 


\subsection{SULFATE REDUCTION VERSUS DCPRB GEOCHEMISTRY}

Table 4 provides a comparison of the optimal sulfate reduction conditions (see Table 1) versus the existing DCPRB groundwater geochemistry (see Table 3). The major microbial competitors to SRB include aerobes, nitrate reducers, manganese reducers, and iron reducers because their respiration is thermodynamically more favorable than SRB respiration. However, SRB will out compete these microbial competitors for carbon substrate and micronutrients (nitrogen and phosphate) if the sulfate concentration is significantly greater than the concentrations of the electron acceptors needed by these microbial competitors (i.e. $\mathrm{O}_{2}, \mathrm{NO}_{3}{ }^{-}, \mathrm{Mn}^{+4}$, and $\mathrm{Fe}^{+3}$ respectively). As can be seen in Table 4, the sulfate concentrations in both areas (i.e. vicinity of DIW-1 and at DCB-49) are significantly greater than the other electron acceptors by two to four orders of magnitude. Although dissolved iron concentrations are significant at DIW-1 and DCB49 , iron speciation analyses $\left(\mathrm{Fe}^{+2} / \mathrm{Fe}\right.$ total) from $\mathrm{DCB}-49$ indicate that most of the dissolved iron is in the reduced form $\left(\mathrm{Fe}^{+2}\right)$.

Methanogens are also a potential competitor to SRB, however methanogen respiration is thermodynamically less favorable than SRB respiration. Additionally, the high sulfate versus low $\mathrm{CO}_{2}$ (the methanogen electron acceptor) concentrations at DIW-1 and DCB-49 indicate that SRB should out compete the methanogens for carbon substrate and micronutrients.

Although the contaminated groundwater in the vicinity of DIW-1 and DCB-49 is such that SRB can out compete other microbes for carbon substrate and micronutrients, some geochemical conditions (i.e. TOC, $\mathrm{pH}$ and $\mathrm{Eh}$ ) may need to be modified to enhance SRB growth. As can be seen in Table 4, the $\mathrm{pH}$ in these areas is less than optimal for SRB, and the Eh in both areas is greater than optimal. Additionally, very little organic carbon substrate is available as indicated by the low total organic carbon (TOC) value. In addition to providing a carbon source, the addition of an appropriate organic carbon substrate(s) will help to increase the $\mathrm{pH}$ and decrease the Eh. However organic carbon alone may not be sufficient to bring the $\mathrm{pH}$ into the optimal range for SRB and a base amendment may need to be added. Table 4 data also suggests that there may be adequate amounts of nitrogen and phosphate micronutrients to support SRB growth initially, but nitrogen and phosphate amendments may also be needed in order to sustain and enhance SRB growth. 
Table 4

DCPRB Groundwater Geochemistry versus Optimal Sulfate Reduction Conditions

\begin{tabular}{|c|c|c|c|}
\hline Parameter & $\begin{array}{l}\text { Optimal SRB Condition } \\
\text { Relative to the Parameter } \\
\end{array}$ & $\begin{array}{l}\text { Average Geochemistry } \\
\text { in the Vicinity } \\
\text { of DIW-1 }\end{array}$ & $\begin{array}{c}\text { Average } \\
\text { DCB-49 } \\
\text { Geochemistry }^{3} \\
\end{array}$ \\
\hline 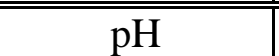 & 5.5 to 9 & 2.46 & 4.12 \\
\hline Eh & 0 to $-150 \mathrm{mV}$ & $628 \mathrm{mV}$ & $461.5 \mathrm{mV}$ \\
\hline $\begin{array}{l}\text { Organic } \\
\text { Carbon }\end{array}$ & \begin{tabular}{|c|}
$0.5-3 \mathrm{M}$ \\
$(44,500$ to $267,000 \mathrm{mg} / \mathrm{L}$ for \\
Lactate $)$
\end{tabular} & $\mathrm{TOC}=6.3 \mathrm{mg} / \mathrm{L}$ & $\mathrm{TOC}=\mathrm{NA}$ \\
\hline $\begin{array}{c}\text { Nitrogen } \\
\left(\mathrm{NH}_{3}^{-} \text {or } \mathrm{NO}_{3}^{-}\right)\end{array}$ & \begin{tabular}{|c|}
$\mathrm{mg} / \mathrm{L}$ range of soluble \\
organic or inorganic nitrogen
\end{tabular} & $\begin{array}{c}\mathrm{NH}_{4}^{+}=\mathrm{NA} \\
\mathrm{NO}_{3}^{-} \text {as } \mathrm{N}=0.53 \mathrm{mg} / \mathrm{L}\end{array}$ & $\begin{array}{c}\mathrm{NH}_{4}^{+}=\mathrm{NA} \\
\mathrm{NO}_{3}^{-} \text {as } \mathrm{N}=\mathrm{NA}\end{array}$ \\
\hline $\begin{array}{l}\text { Phosphate } \\
\left(\mathrm{PO}_{4}^{-3}\right)\end{array}$ & $\begin{array}{c}\text { mg/L range of soluble } \\
\text { organic or inorganic } \\
\text { phosphate }\end{array}$ & Total $\mathrm{PO}_{4}^{-3}$ as $\mathrm{P}=0.14 \mathrm{mg} / \mathrm{L}$ & $\mathrm{P}<0.64 \mathrm{mg} / \mathrm{L}$ \\
\hline $\begin{array}{c}\text { Dissolved } \\
\text { Oxygen }\left(\mathrm{O}_{2}\right)\end{array}$ & 0 -trace & $0.81 \mathrm{mg} / \mathrm{L}$ & $4.6 \mathrm{mg} / \mathrm{L}$ \\
\hline $\begin{array}{l}\text { Nitrate } \\
\left(\mathrm{NO}_{3}^{-}\right)\end{array}$ & $\begin{array}{c}\text { Small fraction of } \mathrm{SO}_{4} \\
\text { concentration }\end{array}$ & $\mathrm{NO}_{3}{ }^{-}$as $\mathrm{N}=0.53 \mathrm{mg} / \mathrm{L}$ & $\mathrm{NO}_{3}{ }^{-}$as $\mathrm{N}=\mathrm{NA}$ \\
\hline $\begin{array}{l}\text { Manganese } \\
\left(\mathrm{Mn}^{+4}\right)\end{array}$ & $\begin{array}{l}\text { Small fraction of } \mathrm{SO}_{4} \\
\text { concentration }\end{array}$ & $\begin{array}{l}\text { Dissolved } \mathrm{Mn}_{4}= \\
38.7 \mathrm{mg} / \mathrm{L}\end{array}$ & $\begin{array}{c}\text { Dissolved Mn }= \\
0.601 \mathrm{mg} / \mathrm{L}^{4}\end{array}$ \\
\hline $\begin{array}{c}\text { Ferric Iron } \\
\left(\mathrm{Fe}^{+3}\right)\end{array}$ & $\begin{array}{c}\text { Small fraction of } \mathrm{SO}_{4} \\
\text { concentration }\end{array}$ & $\begin{array}{c}\text { Dissolved } \mathrm{Fe}=2,136 \mathrm{mg} / \mathrm{L}^{5} \\
\mathrm{Fe}(\mathrm{II}) / \mathrm{Fe}(\text { total })=\mathrm{NA}\end{array}$ & $\begin{array}{c}\text { Dissolved } \mathrm{Fe}=33.4 \\
\mathrm{Fe}(\mathrm{II}) / \mathrm{Fe}(\text { total })=0.976\end{array}$ \\
\hline $\begin{array}{l}\text { Sulfate } \\
\left(\mathrm{SO}_{4}{ }^{-2}\right)\end{array}$ & $\begin{array}{c}\text { Significant } \mathrm{SO}_{4} \\
\text { concentrations; } \\
<5 \mathrm{mM} \mathrm{H}_{2} \mathrm{~S} \text { (higher } \\
\text { concentrations may inhibit } \\
\text { SRB) } \\
\end{array}$ & $\begin{array}{c}\mathrm{SO}_{4}^{-2}=7877 \mathrm{mg} / \mathrm{L} \\
\mathrm{H}_{2} \mathrm{~S}=\mathrm{NA}\end{array}$ & $\begin{array}{c}\mathrm{SO}_{4}^{-2}=410 \\
\mathrm{H}_{2} \mathrm{~S}=\mathrm{NA}\end{array}$ \\
\hline $\begin{array}{c}\text { Acetate } \\
\mathrm{CO}_{2} \\
\mathrm{H}_{2}\end{array}$ & $\begin{array}{c}\text { Eh }>-150 \mathrm{mV} ; \\
\text { presence of significant } \\
\text { sulfate }\end{array}$ & $\begin{array}{c}\text { Acetate }=\mathrm{NA} \\
\mathrm{CO}_{2}=\mathrm{NA} \\
\mathrm{H}_{2}=\mathrm{NA}\end{array}$ & $\begin{array}{c}\text { Acetate }=\mathrm{NA} \\
\mathrm{CO}_{2}=279.79 \mathrm{mg} / \mathrm{L}^{6} \\
\mathrm{H}_{2}=2.07 \mathrm{E}-6 \mathrm{mg} / \mathrm{L}^{6}\end{array}$ \\
\hline
\end{tabular}

$\mathrm{NA}=$ not analyzed

1 Sources: Benner et al., 1999; Chapelle, 1993; EPA, 1999a; Fauque, 1995; Fenchel et al., 1998; Thomas et al., 1999

2 Groundwater data comes from wells DCB-1A, 10, 18A, 18B, 19A, 19B, 21A, 21B, 22A, and 22B (1984-1997); for wells DCB-1A, 18A, 18B, 22A, and 22B data were collected before DIW-1 was installed (Sources: GIMS database and unpublished data collected for the D-Area MagSep project).

3 Source: Washburn, et al., 1999

${ }^{4}$ Dissolved Mn data may include ${ }^{+2}$ and ${ }^{+4}$ species; at the $\mathrm{pH}$ and Eh ranges given above, $\mathrm{Mn}^{+2}$ should be the dominant species present.

5 Dissolved Fe data may include ${ }^{+2}$ and ${ }^{+3}$ species. The maximum Fe concentration of 9237 $\mathrm{mg} / \mathrm{L}$ comes from sampling well DCB-22A before installation of DIW-1. During this sampling event, the $\mathrm{pH}$ ranged from 2.06 to 2.13 and the Eh ranged from 595 to 642, indicating 
that $\mathrm{Fe}^{+2}$ is the dominant species present. Samples collected at DCB-49 yielded ratios of $\mathrm{Fe}^{+2} /$ total $\mathrm{Fe}$ ranging from $0.85-1.0$, also indicating that $\mathrm{Fe}^{+2}$ is the dominant species present in the groundwater next to the DCPRB (Source: Washburn, et al., 1999).

6 One-time sample from DCB-49 using Microseeps Bubble Strip Method (Source: Washburn, et al., 1999)

\subsection{POTENTIAL DCPRB SULFATE REDUCTION PRECIPITATES}

Active and productive SRB will aid in reducing the metal concentrations and raising the $\mathrm{pH}$ in the groundwater downgradient of DIW-1. More specifically, SRB consume sulfate and $\mathrm{H}^{+}$in oxidizing a carbon substrate such as lactate:

$$
2 \mathrm{CH}_{3} \mathrm{CHOHCOO}^{-}+3 \mathrm{SO}_{4}^{-2}+2 \mathrm{H}^{+} \rightarrow 6 \mathrm{HCO}_{3}^{-}+3 \mathrm{H}_{2} \mathrm{~S}(\text { Benner et al., 1999) }
$$

The hydrogen sulfide and bicarbonate generated by SRB then react with metals to remove them from the groundwater producing metal sulfides:

$$
\begin{aligned}
& 3 \mathrm{M}^{+2}+3 \mathrm{H}_{2} \mathrm{~S}+6 \mathrm{HCO}_{3}^{-} \leftrightarrow 3 \mathrm{MS}+6 \mathrm{H}_{2} \mathrm{O}+6 \mathrm{CO}_{2} \\
& \text { (where } \mathrm{M}^{+2} \text { includes } \mathrm{Cd}, \mathrm{Co}, \mathrm{Cu}, \mathrm{Fe}, \mathrm{Mn}, \mathrm{Ni}, \mathrm{Pb} \text { and } \mathrm{Zn} \text { ). }
\end{aligned}
$$

In addition, raising the $\mathrm{pH}$ of the groundwater (from SRB oxidizing a carbon substrate and the addition of a base) would cause the precipitation of hydroxides and carbonates. Table 5 shows likely minerals that would form as a result of sulfate reduction in vicinity of the DCPRB.

Solubility diagrams for iron monosulfide, Al-hydroxide, and Cr-hydroxide indicate how the geochemical conditions created by SRB (and the addition of a base) would favor mineral precipitation. Figure 4, a solubility diagram for ferrous monosulfide, FeS, shows that sulfide minerals become less soluble and mineral precipitation is favored with increasing hydrogen sulfide $\left(\mathrm{H}_{2} \mathrm{~S}\right)$ and with increasing $\mathrm{pH}$. Similarly, Figure 5, a diagram of hydroxide solubility versus $\mathrm{pH}$, shows that $\mathrm{Al}$-hydroxide and $\mathrm{Cr}$-hydroxide precipitation will also be favored by raising the $\mathrm{pH}$. However, under high $\mathrm{pH}$ conditions the hydroxide minerals will become more soluble. In addition, these solubility diagrams also show how changing geochemical conditions in the future, such as a return to low $\mathrm{pH}$ conditions, could increase the solubility of the minerals precipitated by SRB, thus remobilizing the metal constituents. 
Table 5

$\underline{\text { Average Dissolved Metal Concentrations and Potential Mineral Precipitates }}$

\begin{tabular}{|c|c|c|c|}
\hline Parameter & $\begin{array}{c}\text { Average } \\
\text { Concentration } \\
\text { in the } \\
\text { Vicinity of } \\
\text { DIW-1 } 1 \\
\text { (mg/L) }\end{array}$ & $\begin{array}{c}\text { Average } \\
\text { DCB-49 } \\
\text { Concentration } \\
(\mathrm{mg} / \mathrm{L})\end{array}$ & $\begin{array}{l}\text { Possible Mineral Precipitates } \\
\text { Incorporating Metal }\end{array}$ \\
\hline Aluminum & 560.15 & 8.77 & Al-hydroxide $\left(\mathrm{Al}(\mathrm{OH})_{3}\right)$ \\
\hline Cadmium & 0.306 & NA & Greenockite $(\mathrm{CdS})$ \\
\hline Chromium & 0.428 & $<0.1$ & $\begin{array}{l}\text { Cr-hydroxide }\left(\mathrm{Cr}(\mathrm{OH})_{3}\right) \\
\text { Coprecipitate with Pyrite }\left(\mathrm{FeS}_{2}\right)\end{array}$ \\
\hline Cobalt & 1.124 & NA & Coprecipitate with Fe-bearing minerals \\
\hline Copper & 0.599 & NA & Chalcopyrite $\left(\mathrm{FeCuS}_{2}\right)$, Chalcocite $\left(\mathrm{Cu}_{2} \mathrm{~S}\right)$ \\
\hline Iron & 2135.85 & 33.40 & $\begin{array}{l}\text { Chalcopyrite }\left(\mathrm{FeCuS}_{2}\right) \text {, Siderite }\left(\mathrm{FeCO}_{3}\right) \text {, } \\
\text { Pyrite }\left(\mathrm{FeS}_{2}\right) \& \text { other metastable Fe-sulfide } \\
\text { minerals }\end{array}$ \\
\hline Lead & 0.039 & $\mathrm{NA}$ & Galena $(\mathrm{PbS})$ \\
\hline Manganese & 38.702 & 0.601 & $\begin{array}{l}\text { Rhodochrosite }\left(\mathrm{MnCO}_{3}\right) \text {, } \\
\text { Alabandite }(\mathrm{MnS})\end{array}$ \\
\hline Nickel & 4.712 & 0.156 & $\begin{array}{l}\text { Millerite (NiS); Coprecipitate with Al- } \\
\text { bearing minerals }\end{array}$ \\
\hline Zinc & 8.96 & $\mathrm{NA}$ & Sphalerite $(\mathrm{ZnS})$ \\
\hline
\end{tabular}

${ }^{1}$ Groundwater data come from wells DCB-1A, 10, 18A, 18B, 19A, 19B, 21A, 21B, 22A, \& 22B; for wells DCB-1A, 18A, 18B, 22A, and 22B data were collected before wall (DIW-1) was installed (Sources: GIMS database; data collected for D-Area MagSep project).

2 Iron Monosulfide $(\mathrm{FeS})$, Mackinawite $\left(\mathrm{FeS}_{(1-\mathrm{x})}\right)$, Greigite $\left(\mathrm{Fe}_{3} \mathrm{~S}_{4}\right)$

\subsection{POTENTIAL DCPRB GEOCHEMICAL ENHANCEMENTS - BASE, PHOSPHATE, AND NITROGEN AMENDMENT OPTIONS}

Table 6 shows base, phosphate, and nitrogen amendment options for SRB with some of their advantages and disadvantages. Injection of bases such as sodium carbonate, sodium hydroxide, and lime would likely require periodic injections and have the potential for producing high $\mathrm{pH}$ conditions, which are unfavorable for the precipitation of hydroxide minerals and can cause dispersion of clays with the formation. Injection of bases, such as sodium bicarbonate and coal ash, which produce more optimal $\mathrm{pH}$ conditions, still would likely require periodic injections. Solid amendments such as limestone and phosphate rock would require less routine maintenance than the solution bases by having a longer effect on groundwater conditions. In particular, a limestone wall would likely produce $\mathrm{pH}$ conditions most favorable for SRB growth without acting as a source of metals. Groundwater data from the vicinity of DIW-1 and DCB-49 suggest that deactivation by $\mathrm{Fe}^{+3}$ should not be a major problem for a limestone wall. Dolomite is not as reactive as limestone and would likely not be as effective as limestone in bringing the $\mathrm{pH}$ up into 
the optimal sulfate reduction range. If additional $\mathrm{PO}_{4}{ }^{-3}$ is required it may be added in the form of phosphate rock or commercial fertilizers. If additional nitrogen is required, it may also be added in the form of commercial fertilizers. The addition of $\mathrm{NH}_{4}{ }^{+}$would be preferred over the addition of $\mathrm{NO}_{3}{ }^{-}$to avoid any potential stimulation and potential competition from nitrate reducers. However commercial fertilizers are generally fairly soluble and would also likely require periodic replacement or injection.

Of the potential base, phosphate and nitrogen amendments evaluated, the ones that are considered to have the greatest potential for use, if required, at the DCPRB include limestone, phosphate rock, and commercial fertilizers.

Table 6

$\underline{\text { Sulfate Reduction Base, Phosphate, and Nitrogen Amendment Options }}$

\begin{tabular}{|c|c|c|c|}
\hline Media & Form & Advantages & Disadvantages \\
\hline $\begin{array}{l}\text { Sodium } \\
\text { Carbonate }\end{array}$ & Solution & $\begin{array}{l}\text { - Potential to form insoluble metal } \\
\text { carbonates }\end{array}$ & $\begin{array}{cc}- & \text { Periodic injection required } \\
-\quad \text { High equilibrium pH: } \\
\bullet \quad \text { May actually solublize metals } \\
\bullet \quad \text { May disperse clays } \\
-\quad \text { Relatively high concentration of native metals }\end{array}$ \\
\hline $\begin{array}{l}\text { Sodium } \\
\text { Hydroxide }\end{array}$ & Solution & - $\quad$ Readily available & $\begin{array}{cc}- & \text { Periodic injection required } \\
- & \text { High equilibrium } \mathrm{pH}(>12): \\
\bullet & \text { May actually solublize metals } \\
\bullet \quad \text { May disperse clays } \\
\text { - } \quad \text { Relatively high concentration of native metals }\end{array}$ \\
\hline Lime & Solution & - $\quad$ Fairly inexpensive & $\begin{array}{cc}- & \text { Periodic injection required } \\
- & \text { High equilibrium pH }(>10): \\
\bullet & \text { May actually solublize metals } \\
\bullet \quad \text { May disperse clays } \\
\text { - } \quad \text { Relatively high concentration of native metals }\end{array}$ \\
\hline $\begin{array}{c}\text { Sodium } \\
\text { Bicarbonate }\end{array}$ & Solution & - $\quad$ Fairly inexpensive & - $\quad$ Periodic injection required \\
\hline Coal Ash & $\begin{array}{l}\text { Slurry } \\
\text { Solution }\end{array}$ & - $\quad$ Fairly inexpensive & $\begin{array}{l}-\quad \text { Can act as cementing agent } \\
\text { - }\end{array}$ \\
\hline Limestone & Solid & $\begin{array}{c}\text { - Inexpensive } \\
\text { - } \quad \text { Intermediate to low solubility } \\
-\quad \text { Long-term effect } \\
-\quad \text { Optimum equilibrium } \mathrm{pH}(\sim 8) \\
\end{array}$ & $\begin{array}{l}\text { - } \quad \text { Can be deactivated in presence of ferric iron } \\
\text { (FeIII) }\end{array}$ \\
\hline Dolomite & Solid & Inexpensive & Low solubility (lower than limestone) \\
\hline Phosphate Rock & Solid & $\begin{array}{c}\text { Inexpensive } \\
\text { Possible } \mathrm{PO}_{4}^{-3} \text { micronutrient source } \\
\text { Possible formation of insoluble } \\
\text { metal phosphates } \\
\text { - } \quad \text { Intermediate to low solubility } \\
\text { - } \quad \text { Long-term effect }\end{array}$ & $\begin{array}{c}\text { - High equilibrium } \mathrm{pH}: \\
\text { May actually solublize metals } \\
\bullet \quad \text { May disperse clays } \\
\text { - } \quad \text { Relatively high concentration of native metals }\end{array}$ \\
\hline $\begin{array}{l}\text { Commercial } \\
\text { fertilizer }\end{array}$ & Solid & $\begin{array}{cc}- & \text { Readily available } \\
\text { - } & \begin{array}{c}\text { Possible } \mathrm{PO}_{4}^{-3} \text { and } \mathrm{NH}_{4}^{+} \\
\text {micronutrient source }\end{array} \\
\end{array}$ & 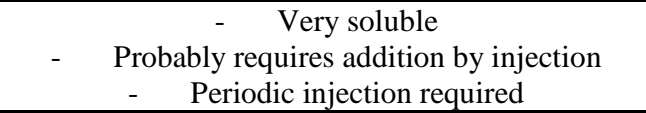 \\
\hline
\end{tabular}




\subsection{D-AREA COAL PILE RUNOFF BASIN (DCPRB) HYDROGEOLOGY}

The east-side of the DCPRB is at an elevation of approximately $130 \mathrm{ft}$-msl, the berm on the west-side is at approximately $125 \mathrm{ft}-\mathrm{msl}$, and the basin's bottom is at an elevation of approximately $121 \mathrm{ft}-\mathrm{msl}$ (see Figure 3). The water elevation within the basin varies from an elevation of 121 to $124.5 \mathrm{ft}-\mathrm{msl}$. The water level in the adjacent discharge ditch, which is approximately $200 \mathrm{ft}$ from the basin at its closest, is at an elevation of approximately $113 \mathrm{ft}-\mathrm{msl}$. The green clay (i.e. the aquitard below the water table aquifer) ranges from an elevation of approximately $65 \mathrm{ft}-\mathrm{msl}$ to $69 \mathrm{ft}-\mathrm{msl}$, based upon cores from wells DCB-20, DCB-23, DCB-24, and DCB-25 (see Figure 6). The DCPRB is located approximately 6000 feet from the Savannah River, and the Savannah River swamp is at an elevation of approximately $90 \mathrm{ft}$-msl. (Phifer, et al., 1996)

The groundwater table around the DCPRB ranges from 0 to 15 feet deep. The water table aquifer ranges from 48 to 53 feet thick and consists of a series of interbedded sand, silt, and clay layers. The water table aquifer is anisotropic and heterogeneous with significant changes in both soil type and hydraulic conductivity with depth. The average horizontal hydraulic conductivity $\left(\mathrm{K}_{\mathrm{h}}\right)$ and average vertical hydraulic conductivity $\left(\mathrm{K}_{\mathrm{v}}\right)$ of the water table aquifer are approximately $5.0 \mathrm{E}-4 \mathrm{~cm} / \mathrm{s}$ and $5.0 \mathrm{E}-5 \mathrm{~cm} / \mathrm{s}$, respectively. The average ratio of horizontal hydraulic conductivity to vertical hydraulic conductivity $\left(\mathrm{K}_{\mathrm{h}} / \mathrm{K}_{\mathrm{v}}\right)$ is approximately 10 . The horizontal hydraulic conductivity of the water table aquifer ranges from $1 \mathrm{E}-3$ to $1 \mathrm{E}-7 \mathrm{~cm} / \mathrm{s}$. Figure 7 shows the hydraulic conductivity profiles produced from cone permeameter and pump tests. The soils from the ground surface to 15 to 25 feet below the ground surface have a fairly low hydraulic conductivity and are very cohesive (i.e. side walls of excavations will remain vertical). Higher conductivity, flowing sand layers are present below the upper low hydraulic conductivity zone (i.e. 15 to 25 feet below the ground surface). The bulk of the water table aquifer groundwater flow occurs within these higher conductivity sand layers. (Phifer, et al., 1996; Lowry, et al., 1999; Phifer, et al., 2000)

Table 7 provides water level data for selected DCPRB wells. As shown at well cluster DCB-20 there is a downward gradient all the way into the Gordon Aquifer. Clusters DCB-21 and DCB-22 also show a downward gradient within the water table. At well cluster DCB-23, which is closer to the Savannah River than DCB-20, there is a downward gradient within the water table wells and an upward gradient across the green clay from the Gordon Aquifer. So between clusters DCB-20 and DCB-23 a head reversal across the green clay occurred. The upward gradient across the green clay may also produce an upward gradient within portions of the lower part of the water table aquifer as evidenced by the data from well cluster DCB-24, where the lowest water table well has a higher water level than the two upper wells. Upward gradients within the water table should increase with decreasing distance to the Savannah River and may be influenced by the ash basins. (Phifer, et al., 1996)

Groundwater flow in the D-Area water table aquifer is predominantly toward the Savannah River. Shallow water table aquifer flow is influenced by local features such as the DCPRB, the discharge ditch, the wetlands between the DCPRB and the ash basins, the ash basins, Beaver Dam Creek, and other wetland/swamp areas. Deeper flow is influenced by the head across the green clay. Figure 8 provides results associated with the borehole flowmeter testing of Well 
DCB-25, which is a fully penetrating water table aquifer well located approximately 90 feet from the basin. Figure 8 shows the ambient and differential ambient flows within the DCB-25 screen produced from the borehole flowmeter testing. As can be seen flow enters the screen and flows upward in the screen from a zone at $\sim 72$ to $\sim 83 \mathrm{ft}-\mathrm{msl}$ and from a second zone at $\sim 88$ to $\sim 94 \mathrm{ft}-$ msl. Then at a zone from $\sim 99$ to $109 \mathrm{ft}-\mathrm{msl}$ the groundwater continues to flow upward but it then flows out of the screen into the formation. The upper part of the water table aquifer probably flows into the screen and downward to the $~ 99$ to $109 \mathrm{ft}-\mathrm{msl}$ zone. The water levels in wells DCB-24A, DCB-24B, and DCB-24C, which are approximately 50 feet side gradient of DCB-25, as shown on Figure 8 are consistent with the flow pattern described above. (Phifer, et al., 1996; WSRC, 1999)

The DCPRB creates a groundwater mound that induces both horizontal and vertical (downward) components of flow away from the basin. The D-Area Interceptor Well (DIW-1) located in the northwest corner of the DCPRB also influences groundwater flow. DIW-1, which is partially penetrating, consists of a 30-foot deep by 240-foot long vertical HDPE membrane, coarse gravel pack (Foster-Dixiana FX-99) on either side of the membrane, and both vertical and horizontal screens in the gravel pack on the upgradient side of the membrane. DIW-1 blocks horizontal flow and may provide a more direct connection from the upper lower conductivity zone, which contains the bulk of the contamination, to the higher permeability sand layers below. (Phifer, et al., 1996)

Table 7 provides water levels from various monitoring well clusters obtained on 1/25/96, after DIW-1 had been installed. Figure 6 provides the location of these and other DCPRB monitoring wells. As shown well clusters DCB-20, DCB-21, DCB-22, and DCB-23 form a line across the northern corner of the DCPRB. The following should be noted concerning this line of wells:

- The northern most portion of the DCPRB is between well clusters DCB-20 and DCB-21; however standing water in the DCPRB rarely exists in this location between the two well clusters. At the time of the Table 7 water level data, standing water in the DCPRB was south of this line of wells.

- Well cluster DCB-21 is located on the upgradient side of DIW-1 and well cluster DCB22 is located on its downgradient side. Water levels in DIW-1 were determined from DIW-1 piezometers DIW-P11A and DIW-P12A, which are essentially in line with this line of wells.

- The discharge ditch is located between well clusters DCB-22 and DCB-23.

- Table 7 also provides the water levels in the DCPRB, DIW-P11A, DIW-P12A, and the discharge ditch.

- The D wells, in clusters DCB-20 and DCB-23, are located in the Gordon Aquifer below the green clay aquitard.

(Phifer, et al., 1996; WSRC, 1999)

The A wells from each cluster (i.e. DCB-20, 21, 22, 23) and the DIW-1 piezometers, which are screened across the water table, in conjunction with the surface water elevation in the discharge ditch produce the water table surface profile as shown in Figure 9. Figure 6 shows the crosssection from which the Figure 9 profile was produced. As can be seen DIW-1 blocks horizontal 
flow and may act as a pathway for the upper part of the water table aquifer to drain to the lower part of the water table aquifer. Figure 10 provides a cross-section of head based upon well cluster DCB-21, DIW-1, and well cluster DCB-22, which also demonstrates this potential DIW-1 drainage feature. This potential DIW-1 drainage is further suggested by a comparison of selected DCB-21, DCB-22, and DCB-23 analytical results as shown in Table 8. Table 8 shows that the contamination is shallowest at DCB-21 and becomes subsequently deeper in at DCB-22 and DCB-23. This deepening of contamination with distance from the DCPRB may also occur naturally due to the water table downward gradients or density differences between contaminated and non-contaminated groundwater. The discharge ditch is hydraulically lower than all of the other points measured, and therefore is a groundwater discharge point for the upper portion of the water table aquifer but probably not for the entire water table aquifer. (Phifer, et al., 1996; GIMS database)

Table 7

$\underline{\text { Selected DCPRB Well Cluster Water Levels (1/25/96) }}$

\begin{tabular}{|c|c|c|c|}
\hline Well/Location & $\begin{array}{c}\text { TOS } \\
\text { (ft-msl) }\end{array}$ & $\begin{array}{c}\text { BOS } \\
(\mathrm{ft}-\mathrm{msl})\end{array}$ & $\begin{array}{c}\text { 1/25/96 Water } \\
\text { Elevation } \\
\text { (ft-msl) }\end{array}$ \\
\hline DCPRB & NA & NA & 122.10 \\
\hline DDCB-20A & 120.9 & 110.9 & 119.50 \\
\hline DCB-20B & 102.8 & 100.3 & 119.05 \\
\hline DCB-20C & 91.9 & 89.4 & 118.53 \\
\hline DCB-20D & 48.7 & 46.2 & 117.18 \\
\hline DCB-21A & 120.1 & 110.1 & 119.03 \\
\hline DCB-21B & 104.7 & 102.2 & 114.84 \\
\hline DCB-21C & 90.8 & 88.3 & 114.68 \\
\hline DIW-P11A & 120.0 & 110.0 & 114.75 \\
\hline DIW-P12A & 119.02 & 109.02 & 114.65 \\
\hline DCB-22A & 119.8 & 109.8 & 114.73 \\
\hline DCB-22B & 103.4 & 100.9 & 114.41 \\
\hline DCB-22C & 90.6 & 88.1 & 114.32 \\
\hline "Discharge Ditch & NA & NA & 112.98 \\
\hline DCB-23A & 115.7 & 105.7 & 113.35 \\
\hline DCB-23B & 96.6 & 94.1 & 111.28 \\
\hline DCB-23C & 89.1 & 86.6 & 111.23 \\
\hline DCB-23D & 51.6 & 49.1 & 114.31 \\
\hline DCB-24A & 1119.4 & 109.4 & 117.75 \\
\hline DCB-24B & 103.0 & 100.5 & 117.68 \\
\hline DCB-24C & 89.7 & 87.2 & 118.50 \\
\hline
\end{tabular}

1) The top of the green clay is at an approximate elevation of 65 to $69 \mathrm{ft}-\mathrm{msl}$

2) The wells highlighted in gray are screen in the Gordon Aquifer (Phifer, et al., 1996; WSRC, 1999) 
Table 8

Selected DCB-21, DCB-22, and DCB-23 Analytical Results (11/97)

\begin{tabular}{|c|c|c|c|c|}
\hline \hline Well & $\mathrm{pH}$ & $\begin{array}{c}\text { Sulfate } \\
(\mathrm{mg} / \mathrm{L})\end{array}$ & $\begin{array}{c}\text { Iron } \\
(\mathrm{mg} / \mathrm{L})\end{array}$ & $\begin{array}{c}\text { Aluminum } \\
(\mathrm{mg} / \mathrm{L})\end{array}$ \\
\hline \hline DCB-21A & 2.2 & 12400 & 1910 & 658 \\
\hline DCB-21B & 3 & 1810 & 113 & 95.6 \\
\hline DCB-21C & 4.4 & 850 & 1.6 & 1.2 \\
\hline DCB-22A & 2.4 & 2700 & 104 & 272 \\
\hline DCB-22B & 3.4 & 2740 & 246 & 128 \\
\hline DCB-22C & 3.8 & 737 & 9.8 & 8.2 \\
\hline DCB-23A & 5.1 & 30.1 & 7.5 & 0.6 \\
\hline DCB-23B & 4.2 & 488 & 16.1 & 0.3 \\
\hline DCB-23C & 4.5 & 1330 & 81.8 & 0.04 \\
\hline DCB-23D & 5.2 & 7.3 & 1.5 & \\
\hline \hline
\end{tabular}

(GIMS database) 


\subsection{D-AREA COAL PILE RUNOFF BASIN (DCPRB) SULFATE REDUCTION APPLICATION OPTIONS}

\subsection{AMENDMENT PLACEMENT IN THE DCPRB}

One approach to improving acid mine drainage from alkaline deficient sites like the DCPRB is to import alkaline material such as limestone or organic materials to amend or place on top of the spoil (i.e. within the DCPRB) in order to obtain alkaline drainage rather than acidic drainage (EPA, 2000). Alkaline drainage has a more neutral $\mathrm{pH}$ and much lower concentrations of sulfate and metals than acid drainage. Therefore direct placement of solid base or solid organic amendments within the DCPRB could be a potential remedial measure. (EPA, 2000) Table 9 provides a summary of the advantages and disadvantages associated with the placement of amendment directly in the basin, along with those of other options.

While the DCPRB is an active operating facility and continues to receive contaminated runoff from the D-Area coal pile (i.e. the coal pile is an active contaminant source to the DCPRB), it is recommended that neither limestone nor any other solid basic material be placed within the basin. Since the basin water contains significant ferric iron (FeIII), the placement of any solid basic material within the water would result in the in the precipitation of ferric hydroxide and the subsequent coating and deactivation of the solid basic material within a short period of time. This could also result in the pluggage of the basin bottom.

Once contaminated runoff discharge to the basin has been discontinued and the basin has been de-watered, the placement and mixing of limestone chips with the basin soils is recommended to stabilize the soils. Limestone is recommended over lime due to the elevated $\mathrm{pHs}$ that could be produced by the lime that could lead to remobilization of some metals from the basin soils. Limestone would produce a $\mathrm{pH}$ more in line with the minimum solubility of most metal hydroxides (see Figure 5 for aluminum and chromium hydroxides). It is assumed that much of the iron currently bound to the basin soils is in the form of ferric hydroxide. A leach test would need to be performed to evaluate the effectiveness of this stabilization method.

Placement of solid organic substrate within the basin would produce more reduced conditions and promote sulfate reduction and the precipitation of metal sulfides. However, the impact on redox sensitive metals and radionuclides such as arsenic, iron, chromium, uranium, and selenium that are currently bound up in the basin sediments and soils would have to be considered prior to the placement of organic substrate in the basin (WSRC, 1999). The reduced forms of arsenic oxides and iron hydroxides are more mobile than the oxidized forms. Therefore the use of organic substrate in the basin could actually mobilize arsenic and iron. Under these conditions the iron may remain bound to the soil in the form of a sulfide. The reduced forms of chromium and uranium hydroxides are less mobile than the oxidized forms; and the use of organic substrate in the basin could actually bind these metals more tightly. The potential for the production of methyl mercury and the pluggage of the basin bottom would also have to be considered. At a minimum, a leach test would need to be performed to address the above issues in order to seriously consider organic substrate placement within the basin. While the basin continues to receive contaminated runoff from the coal pile, placement of solid organic substrate in the basin is not recommended, since the mass of contaminants can not be estimated in order to determine 
the quantity of substrate required. Its use after runoff from the coal pile has been discontinued is probably not warranted, since at that point it would probably be no more effective than only placing a solid base within the basin.

\subsection{TRADITIONAL PERMEABLE REACTIVE BARRIER (PRB)}

According to EPA a Permeable Reactive Barrier (PRB) "is a passive in situ treatment zone of reactive material that degrades or immobilizes contaminants as ground water flows through it. ... Natural gradients transport contaminants through strategically placed treatment media." The traditional PRB consists of a continuous trench "installed across the entire path of the plume" that "is filled with the reactive media." In order to prevent by-pass flow of contaminated groundwater, PRBs are typically installed over the entire thickness of the water table aquifer, are typically keyed into an aquitard, and typically have a width slightly greater than that of the plume. (EPA,1999b)

If traditional PRB technology is utilized to remediate the DCPRB plume, it has been previously recommended that the Sulfate Reduction PRB be configured with an upgradient limestone trench and a downgradient sulfate reduction trench (Phifer and Denham, 2000). This traditional PRB configuration results in two assumed 1000 -foot long by 65 -foot deep by 3 -foot wide trenches, one filled with limestone and one with limestone and organic solids, at an estimated capital cost approaching three million dollars. Another major drawback to the use of a traditional PRB configuration at the DCPRB, particularly for the trench containing the organic solids, is that the mass of contaminants can not be estimated in order to determine the quantity of organic solids required. This inability to estimate the contaminant mass occurs, since the DCPRB will continue to receive contaminated runoff from the D-Area coal pile for the foreseeable future. A summary of other disadvantages, along with the advantages of the traditional PRB option are provided in Table 9 along with those of other options. For these reasons the use of a traditional PRB for remediation of the DCPRB plume is not recommended.

\subsection{MODIFIED PERMEABLE REACTIVE BARRIER (PRB)}

A modified PRB, as proposed, has the following two primary differences from a traditional PRB:

- The PRB is not keyed into an aquitard, and

- An injection distribution system for injection of liquid or soluble media is provided to replenish, augment, and/or optimize the solid permeable reactive media (Phifer and Denham, 2000).

These differences allow the modified PRB, as proposed, to overcome the primary disadvantages of a traditional PRB installation at the DCPRB (i.e. cost and the inability to determine the quantity of organic solids required due to the presence of an active contaminant source). Table 9 provides a summary of the advantages and disadvantages associated with the modified PRB option along with those of other options. The primary disadvantage associated with a modified PRB at the DCPRB is the extent of the characterization and modeling required to ensure that the contaminated groundwater flows in series first through the upgradient limestone trench and then through the downgradient sulfate reduction trench without bypassing the second trench. This 
option probably requires the most thorough characterization and modeling of all the options evaluated. (Phifer and Denham, 2000)

\subsection{GEOSIPHON/GEOFLOW SYSTEM}

A GeoSiphon ${ }^{\mathrm{TM}}$ system is established by connecting a location of higher-pressure head to a location of lower-pressure head with a siphon to induce contaminated water flow through a permeable treatment media. The first location with the higher-pressure head is located within the contaminated portion of an aquifer. The second location with the lower-pressure head can be located within the same aquifer, another aquifer, the unsaturated (vadose) zone, a surface water body, or the ground surface. The two locations with a difference in hydraulic head are selected to provide the head difference necessary (substantial head difference) to drive the contaminated water through a permeable treatment media at the flow rate required. The siphon bypasses the natural resistance to groundwater flow inherent in the aquifer porous media and instead utilizes the natural energy for treatment. Bypassing the aquifer's natural resistance to flow results in greater flow rates through the siphon than can be obtained naturally within the aquifer. The permeable treatment media can be located at the siphon inlet, at the siphon outlet, or at both. (Phifer, et al., 2001)

A GeoSiphon treatment system, which was located immediately downgradient from monitor well DCB-49 (see Figure 6), has been successfully operated at the DCPRB. "The pilot scale treatment system consisted of a primary limestone treatment trench to remove predominately aluminum by precipitation, a siphon to induce contaminated groundwater flow between the trench and the secondary treatment system, and a secondary treatment system" (oxidation and $\mathrm{pH}$ adjustment) "for predominately iron precipitation." (Washburn, et al., 1999)

A sulfate reduction GeoSiphon system for the treatment of the DCPRB contaminated groundwater would probably consist of an in-situ limestone treatment/extraction trench, a siphon, and an ex-situ passive flow-through bioreactor. While such a system is possible and a DCPRB GeoSiphon has been demonstrated on a pilot scale, the available head to drive the system is fairly low and variable and will significantly decrease once discharge to the DCPRB is discontinued. For this reason remediation of the DCPRB plume utilizing this option is not recommended. See Table 9 for a summary of other advantages and disadvantages associated with the GeoSiphon option along with those of other options.

\subsection{GEOFIX SYSTEM}

A GeoFix system utilizes the natural hydraulic head difference between two points to passively induce the flow of clean water through a soluble permeable treatment media to create a treatment media solution, which is subsequently brought into contact with contaminated groundwater. A sulfate reduction GeoFix system for the treatment of the DCPRB contaminated groundwater would probably consist of a vadose zone trench containing a low solubility solid base and a low solubility solid organic substrate into which precipitation runoff from a significant area is directed. The runoff, which is directed into the trench, would dissolve some of the base and organic and subsequently recharge the upper portion of the DCPRB contaminated water table aquifer where treatment would occur. 
While the GeoFix technology is promising it is an immature technology and is therefore not currently recommended for deployment at the DCPRB. Table 9 provides a summary of the advantages and disadvantages associated with the GeoFix option along with those of other options.

\subsection{INJECTION WELL SYSTEM}

Several vertical injection well systems have been utilized and documented for the injection of carbon substrates and micronutrients into groundwater by gravity or pumping for the bioremediation of chlorinated solvents. The Interstate Technology regulatory Cooperation (ITRC, 1998) states the following in relation to chlorinated solvent bioremediation using these types of systems:

"These types of systems are useful for reducing contaminant levels in low-concentration plumes, or as a polishing step for other primary treatment technologies. They do not provide hydraulic containment, and may produce mounding of the piezometric surface which may cause the plume to expand somewhat in aerial extent." (ITRC, 1998)

The ITRC (ITRC, 1998) appears to be biased toward recirculation (extraction and reinjection) systems for the in-situ bioremediation of chlorinated solvents, since it "allows contaminated fluid to pass through an active treatment zone many times before exiting." The recirculation feature is allows the treatment of higher concentrations of chlorinated solvents by providing more residence times for solvent degradation to occur. However recirculation systems will not be considered further for the DCPRB sulfate reduction due to the following:

- Continuous reinjection into the generally low permeability DCPRB water table aquifer (see Section 5.0) will be very difficult and maintenance intensive.

- Such a system would be an active system that would require long-term operation and maintenance due to the continual receipt of contaminated runoff by the DCPRB from the coal pile for the foreseeable future.

While recirculation systems do not warrant further consideration, simple vertical, injection well systems do. Table 9 provides a summary of the advantages and disadvantages associated with the injection well option along with those of other options. The primary advantages associated with the use of injection wells as follows:

- A high degree of flexibility is provided relative to the media injected, the location of injection, and the timing of injection.

- Due to the continual receipt of contaminated runoff by the DCPRB from the coal pile for the foreseeable future, injection wells allow for the periodic injection of treatment media to compensate for the continual receipt of contaminated runoff by the DCPRB.

The injection of carbons substrates and micronutrients through vertical injection wells can be controlled so that biofouling should not be a problem by utilizing periodic pulsed injection and 
selecting the organic carbons appropriately. However the injection of a base through vertical injection wells is not recommended at the DCPRB due to the following:

- Base injection could result in precipitation pluggage of the injection wells due to the high concentration of metals and the near instantaneous reaction kinetics

- High concentrations and/or large volumes of base would be required due to the low pHs

\subsection{CPT INJECTION}

CPT injection has been utilized for both the bioremediation of chlorinated solvents (Koenigsberg, 2000) and the remediation of low pH/metals/radionuclide plumes (WSRC, 2001). CPT injection consists of one-time injection events that do not leave any equipment or facilities in the field after an injection event has been completed. Due to the continued receipt of contaminated runoff by the DCPRB for the foreseeable future, multiple CPT mobilizations and injection events would be required. Additionally the bulk of the contamination is located at the top of the water table aquifer in a low permeability zone, this will make CPT injection difficult and require a fairly close spacing in order to obtain the required coverage. For these reasons the use of CPT injection for DCPRB sulfate reduction is not recommended. See Table 9 for a summary of other advantages and disadvantages associated with the CPT injection option along with those of other options.

\subsection{DIW-1 INJECTION}

The D-Area Interceptor Well (DIW-1) was installed in 1995 at the northwest corner of the DArea CPRB, which is the area of the plume that is most highly contaminated. DIW-1 is a partially penetrating well screened within the upper most contaminated portion of the aquifer. It consists of a 30-foot deep by 240-foot long vertical HDPE membrane, coarse gravel pack (Foster-Dixianna FX-99) on either side of the membrane, and four vertical well screens and four horizontal slotted drainage pipes on the upradient side of the membrane. Two horizontal slotted drainage pipes extend out along each wing of the HDPE membrane from its center point. Each drainage pipe is assessable from land surface through its own vertical riser. Hydraulic testing of DIW-1 was conducted in 1996. This testing indicated that the use of the coarse gravel pack and horizontal slotted drainage pipes provided a more even distribution of groundwater collection across the entire width of the contaminant plume intercepted by DIW-1. (Phifer, et al., 1996) This location and configuration of DIW-1 makes it one of the best possible installations for the injection of treatment media in this highly contaminated portion of the plume.

The use of DIW-1 for injection shares most of the advantages and disadvantages associated with the use of injection wells (see section 6.6). Therefore for the same reason DIW-1 is considered ideal for the injection of carbon substrates and micronutrients but not for the injection of bases. See Table 9 for a summary of other advantages and disadvantages associated with the DIW-1 injection option along with those of other options. 


\subsection{GROUNDWATER EXTRACTION WITH EX-SITU BIOREACTOR}

A DCPRB groundwater extraction with ex-situ bioreactor system would consist of recovery wells to extract the contaminated groundwater and an above grade bioreactor. The use of a groundwater extraction to treat the groundwater will result in an extended period that the system must operate in order to reduce the contaminant levels to below that required by the regulatory agencies. This extended period of operation results from the fact that pump and treat systems generally require the contaminants to be in the aqueous phase in order for them to be extracted from the subsurface and treated. For many of the metal contaminants at the DCPRB only a fraction of the total mass is in the aqueous phase; a significant fraction of the mass may exist in another phase due to partitioning, adsorption/absorption, precipitation, solubility, cation exchange, etc. The mass of contaminants in these other phases can be subsequently slowly released to the aqueous phase as remediation proceeds. This slow release requires that multiple groundwater pore volumes be extracted and treated in order to reach regulatory standards. This in turn requires that the system be operated for an extended period, beyond the time that discharge to the DCPRB is discontinued, with the associated high energy, operating, and maintenance costs. (Phifer, et al., 1998)

For this reason alone a groundwater extraction with ex-situ bioreactor system is not recommended for remediation of the DCPRB groundwater plume. See Table 9 for a summary of other advantages and disadvantages associated with the groundwater extraction with ex-situ bioreactor option along with those of other options.

\subsection{GROUNDWATER EXTRACTION WITH CONSTRUCTED WETLANDS}

In order to treat the DCPRB groundwater with constructed wetlands the following would be required in sequence: groundwater extraction, some type of alkalinity generating system (such as an anoxic limestone drain (ALD) or a successive alkalinity producing system (SAPS)), and an anaerobic constructed wetlands (Thomas, et al., 1999; EPA, 2000). Such a system would be an active system, similar to the groundwater extraction with ex-situ bioreactor system of section 6.9, since groundwater extraction through pumping would be required. The topography of the area and the geohydrology of the aquifer will not allow for passive extraction of the groundwater for treatment in a constructed wetland. Long-term operation of the system would be required for the same reasons it is required for the groundwater extraction with ex-situ bioreactor system of section 6.9.following reasons:

- The DCPRB will continue to receive contaminated runoff from the coal pile for the foreseeable future.

- The slow release of contaminants from the partitioned, adsorbed/absorbed, precipitated, cation exchange, etc phases to the aqueous phase as remediation proceeds, even after discharge to the DCPRB has been discontinued.

For these reasons the use of constructed wetland for DCPRB sulfate reduction is not recommended. See Table 9 for a summary of other advantages and disadvantages associated with the constructed wetland option along with those of other options. 


\subsection{APPLICATION OPTION SUMMARY}

Table 9 provides a summary of the advantages and disadvantages associated with each of the sulfate reduction application options. Table 10 provides a summary of the recommendations associated with each option relative to the application of the organic substrate and base to promote sulfate reduction remediation of the DCPRB groundwater plume. The following are the primary reasons and associated options that are not recommended for use:

- Any option, which involves groundwater extraction and ex-situ treatment of this metals contaminated groundwater, has been eliminated from consideration due to the extended period of operation which will be required beyond the time that discharge to the DCPRB is discontinued (see section 6.9 for a detailed discussion). These include the GeoSiphon/GeoFlow system option, the groundwater extraction with ex-situ bioreactor option, and the groundwater extraction with constructed wetlands option.

- Any option, which involves injection of a base solution into the groundwater, has been eliminated from consideration due to the high potential for precipitation pluggage and the high concentrations and/or large volumes that would be required under the conditions present at the DCPRB. These include the GeoFix system option, the injection well system option, the CPT injection option, and the use of DIW-1 as an injection system option for the application of a base solution.

- Any option, which involves a high capital cost, has been eliminated from consideration in favor of options with lower capital cost. These high-capital cost options include the traditional permeable reactive barrier and the groundwater extraction with ex-situ bioreactor.

- Any option, which involves the in situ use of a solid organic substrate, has been eliminated from consideration due to the inability to determine the quantity of solid organic substrate required, since the DCPRB will continue to be operating into the indefinite future. These options include the traditional permeable reactive barrier and the modified PRB.

- The media placement in the bottom of the DCPRB is not recommended so long as the basin remains in operation due to potential deactivation of the base and the inability to determine the quantity of solid organic substrate required. Additionally the use of solid organic substrate directly in the basin is not recommended, unless the potential negative impacts upon redox sensitive metals and radionuclides contained within the soils of the basin are appropriately addressed.

- The GeoFix system is not recommended due to the immaturity of the technology.

- CPT injection is not recommended for either the organic substrate or the base. This is due to the multiple CPT mobilizations and injections that would be required, since the DCPRB will continue to be operating into the indefinite future, and due to the difficulty of injecting into the upper, low permeability portion of the aquifer.

The options, which have the most potential for use in the application of the organic substrate and base at the DCPRB, include the following:

- Once discharge to the DCPRB is discontinued it is recommended that at base (preferably limestone) be blended into the basin soils. 
- The option considered most feasible for application of a base is a modified permeable reactive barrier.

- The options considered most feasible for application of organic substrate include an injection well system and use of DIW-1 as an injection system. 
Table 9

Sulfate Reduction Application System Options Advantages and Disadvantages

\begin{tabular}{|c|c|c|}
\hline Option & Advantages & $\begin{array}{l}\text { Disadvantages } \\
\end{array}$ \\
\hline $\begin{array}{l}\text { Media Placement } \\
\text { in Bottom of } \\
\text { DCPRB }\end{array}$ & $\begin{array}{cc} & \text { Fairly easy access } \\
- & \text { In-situ } \\
- & \text { Passive } \\
-\quad \text { No operating and maintenance costs } \\
-\quad \text { Dissolved media should follow the same flow path as the current contaminant } \\
\text { plume }\end{array}$ & $\begin{array}{c}\text { - Continual receipt of contaminated runoff from the coal pile for the foreseeable } \\
\text { future invalidates the use of this option } \\
\text { - Could result in the pluggage of the basin bottom } \\
\text { - Potential deactivation of solid base in the presence of dissolved ferric iron (FeIII) } \\
\text { Organic substrate could have a potentially negative impact on redox sensitive } \\
\text { metals and radionuclides }\end{array}$ \\
\hline $\begin{array}{c}\text { Traditional } \\
\text { Permeable } \\
\text { Reactive Barrier } \\
\text { (PRB) }\end{array}$ & $\begin{array}{c}-\quad \text { Passive } \\
-\quad \text { In-situ } \\
-\quad \text { Emplaced vertically and perpendicular to natural horizontal groundwater flow } \\
\quad \text { direction } \\
-\quad \text { No operating and maintenance costs }\end{array}$ & 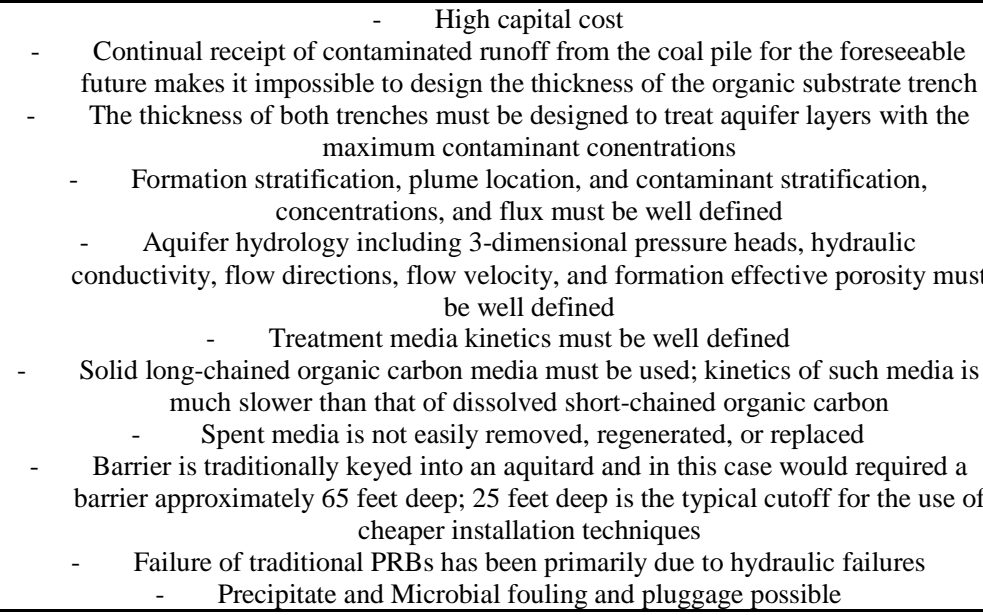 \\
\hline $\begin{array}{l}\text { Modified PRB } \\
\text { (Internal Injection } \\
\text { Distribution } \\
\text { System and not } \\
\text { keyed into } \\
\text { aquitard) }\end{array}$ & $\begin{array}{c}-\quad \begin{array}{c}\text { Passive } \\
\text { In-situ }\end{array} \\
\text { - } \quad \text { Emplaced vertically and perpendicular to natural horizontal groundwater flow } \\
\quad \text { direction } \\
\text { May take advantage of aquifer downward gradients } \\
-\quad \text { Not keyed into the green clay } \\
-\quad \text { Flexibility provided by the ability to inject short-chained organic carbon and bases } \\
-\quad \text { Low operating and maintenance costs } \\
\text { - Injection option allows biocide or cleaning material to mitigate unwanted } \\
\text { plugging or fouling } \\
-\quad \text { Bioaugmentation possible (sulfate reducers) }\end{array}$ & $\begin{array}{c}\text { - Continual receipt of contaminated runoff from the coal pile for the foreseeable } \\
\text { future makes it impossible to design the thickness of the organic substrate trench } \\
\text { - The thickness of both trenches must be designed to treat aquifer layers with the } \\
\text { maximum contaminant conentrations } \\
\text { - } \\
\text { Formation stratification, plume location, and contaminant concentrations must be } \\
\text { well defined } \\
\text { - } \quad \text { Aquifer hydrology including 3-dimensional pressure heads, hydraulic } \\
\text { conductivity, and flow directions must be well defined } \\
\text { - } \begin{array}{c}\text { Solid spent media is not easily removed, regenerated, or replaced; however the } \\
\text { injection distribution system allows injection of dissolved short-chained organic } \\
\text { carbon and bases }\end{array} \\
\text { - Failure of traditional PRBs has been primarily due to hydraulic failures } \\
\text { - Precipitate and Microbial fouling and pluggage possible } \\
\text { Extensive characterization and modeling required to ensure series flow of the } \\
\text { contaminated groundwater through both PRB trenches }\end{array}$ \\
\hline
\end{tabular}


Table 9

$\underline{\text { Sulfate Reduction Application System Options Advantages and Disadvantages (continued) }}$

\begin{tabular}{|c|c|c|}
\hline Option & " Advantages & "Disadvantages \\
\hline $\begin{array}{c}\text { GeoSiphon/ } \\
\text { GeoFlow System }\end{array}$ & $\begin{array}{c}\text { - } \quad \text { Passive } \\
\text { - } \quad \text { Ex-situ treatment } \\
\text { - While the plume must be located to be extracted; much less contaminant and } \\
\text { aquifer hydrologic information is required for successful implementation than } \\
\text { required for PRBs } \\
\text { - } \quad \text { Media quantity can be based upon average contaminant concentrations since the } \\
\text { concentrations are averaged during groundwater recovery and transport to the } \\
\text { treatment cell } \\
\text { - } \quad \text { h high degree of flexibility is provided relative to the utilization of organic } \\
\text { carbon, nutrients, etc } \\
\text { - Modifications to the treatment system can be easily made based upon influent } \\
\text { changes over time }\end{array}$ & 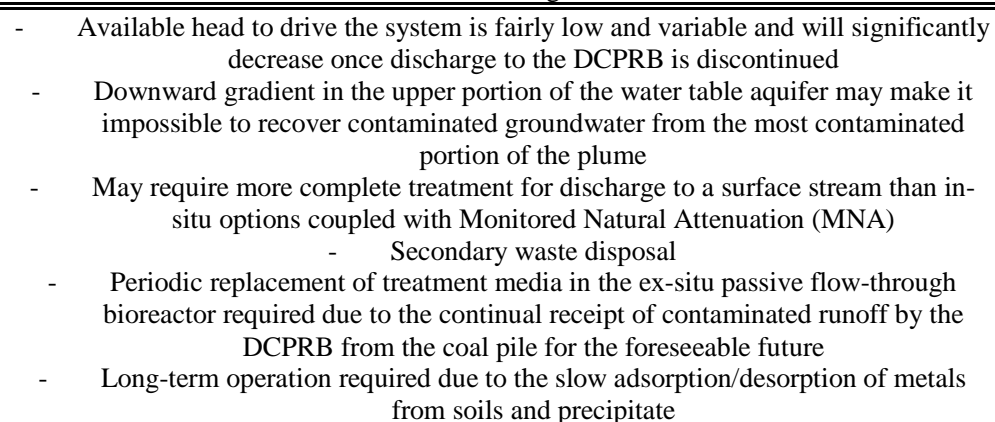 \\
\hline GeoFix System & $\begin{array}{c}-\quad \text { Passive } \\
-\quad \text { In-situ } \\
\text { Low operating and maintenance costs } \\
-\quad \text { Media can be easily replaced } \\
\text { - While the plume must be located to be extracted; much less contaminant and } \\
\text { aquifer hydrologic information is required for successful implementation than } \\
\text { required for PRBs }\end{array}$ & $\begin{array}{l}\text { - Immature technology } \\
\text { - Intermittent treatment based upon precipitation and associated runoff } \\
\text { Must utilize solid media that is sufficiently but not too soluble } \\
\text { High concentration of soluble organic solids could lead to microbial fouling and } \\
\text { pluggage }\end{array}$ \\
\hline $\begin{array}{l}\text { Injection Well } \\
\text { System }\end{array}$ & $\begin{array}{c}\text { In-situ } \\
\text { - Wells can be selectively screened across zones of high contamination } \\
\text { While the plume must be located to be extracted; much less contaminant and } \\
\text { aquifer hydrologic information is required for successful implementation than } \\
\text { required for PRBs } \\
\text { - } \begin{array}{c}\text { Flexibility provided by the ability to inject various short-chained organic carbons, } \\
\text { bases, nutrients, etc when and where required }\end{array} \\
\text { - } \begin{array}{c}\text { Periodic injections are possible to compensate for the continual receipt of } \\
\text { contaminated runoff by the DCPRB }\end{array} \\
\text { - Injection could be pulsed to prevent biofouling and expand zone of influence } \\
\text { - Injected nutrients follow most permeable areas increasing likelihood of contact } \\
\text { with migrating sulfate } \\
\text { Bioaugmentation possible (sulfate reducers) }\end{array}$ & 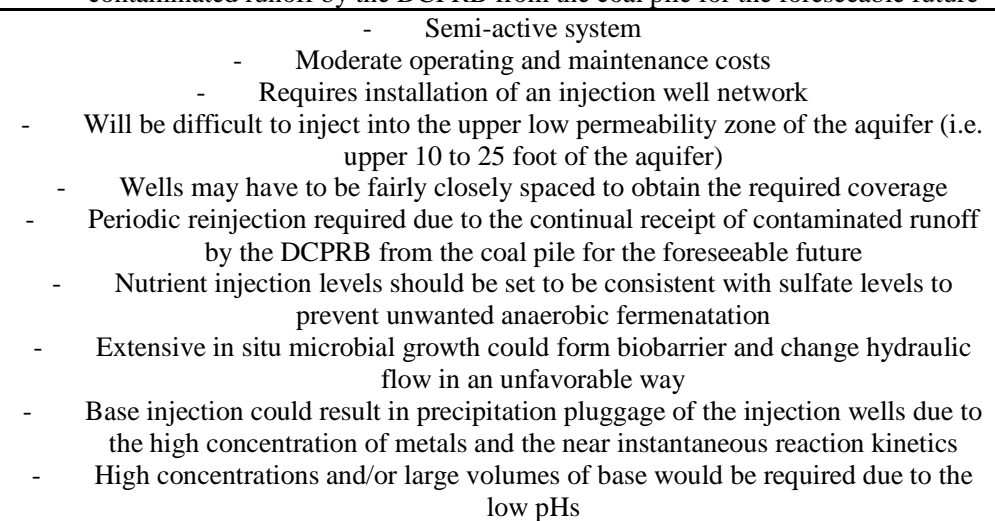 \\
\hline
\end{tabular}


Table 9

$\underline{\text { Sulfate Reduction Application System Options Advantages and Disadvantages (continued) }}$

\begin{tabular}{|c|c|c|}
\hline Option & Advantages & Disadvantages \\
\hline CPT Injection & $\begin{array}{l}\text { - } \\
\text { - } \quad \text { In-situ } \\
\text { While the plume must be located to be extracted; much less contaminant and } \\
\text { aquifer hydrologic information is required for successful implementation than } \\
\text { required for PRBs } \\
\text { - A high degree of flexibility is provided relative to the utilization of organic } \\
\text { carbon, nutrients, etc } \\
\text { - } \quad \begin{array}{c}\text { Flexibility provided by the ability to inject various short-chained organic carbon, } \\
\text { bases, nutrients, etc when and where required }\end{array}\end{array}$ & $\begin{array}{l}\text { - Semi-active system } \\
\text { Will require additional CPT mobilizations and injections over time due to the } \\
\text { continual receipt of contaminated runoff by the DCPRB from the coal pile for the } \\
\text { foreseeable future } \\
\text { Will be difficult to inject into the upper low permeability zone of the aquifer (i.e. } \\
\text { upper } 10 \text { to } 25 \text { foot of the aquifer) } \\
\text { CPT injections may have to be fairly closely spaced to obtain the required } \\
\text { coverage }\end{array}$ \\
\hline $\begin{array}{l}\text { Use of DIW-1 as } \\
\text { an Injection } \\
\text { System }\end{array}$ & $\begin{array}{c}\text { - } \quad \text { In-situ } \\
\text { - DIW-1 already exists in the area of highest contamination } \\
\text { permeability zone of the aquifer } \\
\text { - } \quad \text { A high degree of flexibility is provided relative to the utilization of organic } \\
\text { carbon, nutrients, etc }\end{array}$ & $\begin{array}{c}\text { - Semi-active system } \\
\text { - } \quad \begin{array}{c}\text { Moderate operating and maintenance costs } \\
\text { Carbon steel and stainless steel portions of DIW-1 have corroded significantly } \\
\text { within the low pH groundwater environment }\end{array} \\
\text { - } \quad \begin{array}{c}\text { Periodic reinjection required due to the continual receipt of contaminated runoff } \\
\text { by the DCPRB from the coal pile for the foreseeable future }\end{array} \\
\text { - } \quad \text { Nutrient injection levels should be set to be consistent with sulfate levels to } \\
\text { prevent unwanted anaerobic fermenatation } \\
\text { - } \quad \text { Extensive in situ microbial growth could form biobarrier and change hydraulic } \\
\text { flow in an unfavorable way } \\
\text { - } \quad \begin{array}{c}\text { Base injection could result in precipitation pluggage of the injection wells due to } \\
\text { the high concentration of metals and the near instantaneous reaction kinetics }\end{array} \\
\text { - High concentration and/or large volume of base required due to the low pH }\end{array}$ \\
\hline $\begin{array}{c}\text { Groundwater } \\
\text { Extraction with } \\
\text { Ex-situ Bioreactor }\end{array}$ & $\begin{array}{l}\text { - While the plume must be located to be extracted; much less contaminant and } \\
\text { aquifer hydrologic information is required for successful implementation than } \\
\text { required for PRBs } \\
\text { - } \\
\text { Bioreactor design can be based upon average contaminant concentrations since the } \\
\text { concentrations are averaged during groundwater recovery and transport to the } \\
\text { bioreactor } \\
\text { - } \\
\text { A high degree of flexibility is provided relative to the utilization of organic } \\
\text { carbon, nutrients, etc } \\
\text { - } \\
\text { Modifications to the treatment system can be easily made based upon influent } \\
\text { changes over time }\end{array}$ & $\begin{array}{l}-\quad \text { High capital cost } \\
\text { - Active system (both pumping and treatment) } \\
\text { Long-term operation and maintenance of the pumping and treatment systems } \\
\text { would be required for two reasons: 1) the continual receipt of contaminated runoff } \\
\text { by the DCPRB from the coal pile for the foreseeable future; } 2 \text { ) the slow } \\
\text { adsorption/desorption of metals from soils and precipitate } \\
-\quad \text { Ex-situ } \\
-\quad \text { High operating and maintenance costs } \\
-\quad \text { External power required } \\
\text { - Secondary waste disposal } \\
\text { May require more complete treatment for discharge to a surface stream than in- } \\
\text { situ options coupled with Monitored Natural Attenuation (MNA) }\end{array}$ \\
\hline $\begin{array}{l}\text { Groundwater } \\
\text { Extraction with } \\
\text { Constructed } \\
\text { Wetlands }\end{array}$ & $\begin{array}{c}-\quad \text { Low operating and maintenance costs } \\
-\quad \text { Media can be replaced if neccessary } \\
\text { - While the plume must be located to be extracted; much less contaminant and } \\
\text { aquifer hydrologic information is required for successful implementation than } \\
\text { required for PRBs }\end{array}$ & $\begin{array}{l}\text { - Active system (pumping above grade required) } \\
\text { Long-term operation and maintenance of the pumping system would be required } \\
\text { for two reasons: 1) the continual receipt of contaminated runoff by the DCPRB } \\
\text { from the coal pile for the foreseeable future; 2) the slow adsorption/desorption of } \\
\text { metals from soils and precipitate } \\
-\quad \text { External power required } \\
-\quad \text { Secondary waste disposal } \\
\text { May require more complete treatment for discharge to a surface stream than in- } \\
\text { situ options coupled with Monitored Natural Attenuation (MNA) }\end{array}$ \\
\hline
\end{tabular}




\section{Table 10}

\section{Sulfate Reduction Application Systems Options Recommendations}

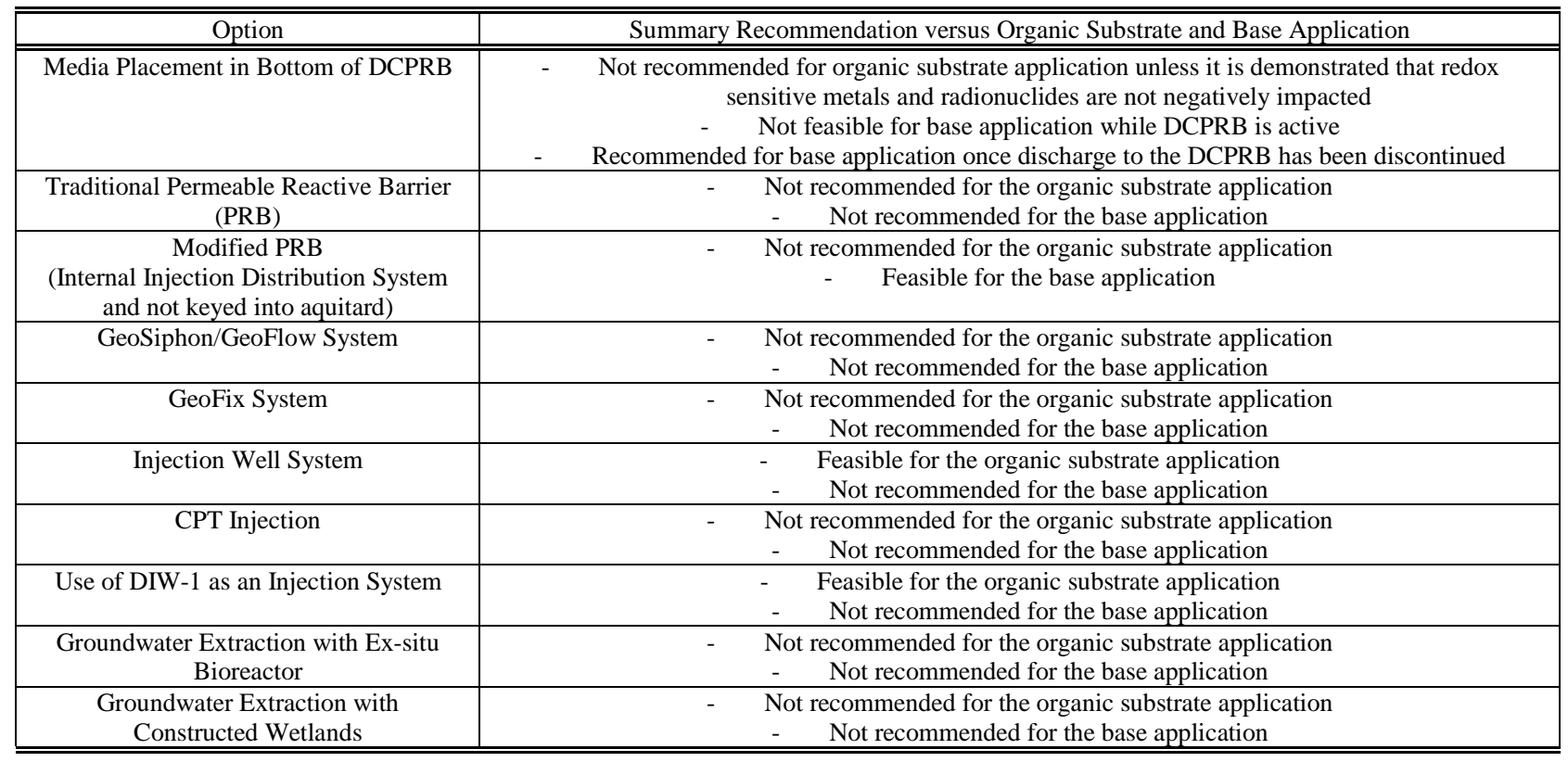




\subsection{SUMMARY AND RECOMENDATIONS}

\subsection{SUMMARY}

A literature review has been performed to assess the feasibility of sulfate reduction as a means to remediate the D-Area Coal Pile Runoff Basin (DCPRB) low $\mathrm{pH} / \mathrm{metals} /$ sulfate groundwater plume. This literature review focused upon definition of the optimal conditions for sulfate reduction, a comparison of the current DCPRB groundwater conditions versus the optimal sulfate reduction conditions, the likely metal precipitates produced, the organic substrate, bases, and other amendments that might be necessary to promote sulfate reduction, and application options

The DCPRB contaminated groundwater is such that sulfate reducing bacteria (SRB) can out compete other microbes for carbon substrates and micronutrients, however some geochemical conditions need to be modified to enhance SRB growth. Organic carbon substrate(s) needs to be added, the $\mathrm{pH}$ needs to be raised, and the Eh needs to be lowered. In addition to providing a carbon source, the addition of an appropriate organic carbon substrate(s) will help to increase the $\mathrm{pH}$ and decrease the Eh. However organic carbon alone may not be sufficient to bring the $\mathrm{pH}$ into the optimal range for SRB and a base amendment may need to be added. There may be adequate amounts of nitrogen and phosphate micronutrients to support SRB growth initially, but nitrogen and phosphate amendments may also be needed in order to sustain and enhance SRB growth. Sulfate reduction by SRB results in the generation of hydrogen sulfide and bicarbonate and an increase in the $\mathrm{pH}$. This results in the precipitation of metal sulfides, hydroxides and carbonates.

Of the organic carbon substrates evaluated lactate, Hydrogen Release Compound (HRC), and vegetable oil are considered to have the greatest potential to promote SRB growth and subsequent sulfate reduction at the DCPRB. These potential substrates have different biological and physical characteristics, which could make either their use alone or in combination beneficial. Lactate, which is highly soluble and immediately available to SRB, could be used at the beginning of a project in order to increase SRB numbers. HRC, which sinks, has a low solubility, and is immediately available to SRB, could be used to provide a long-term carbon source in the lower portion of the aquifer. Vegetable oil, which floats, has a low solubility, and requires degradation to be available to SRB, could be used to provide a long-term carbon source in the most contaminated portion of the aquifer. The different properties of these potential carbon substrates could be exploited in combination to produce a more effective system than could be obtained by their use alone.

Of the potential base, phosphate, and nitrogen amendments evaluated, limestone (to increase the $\mathrm{pH}$ ), phosphate rock (to increase the $\mathrm{pH}$ and as a source of phosphate), and commercial fertilizers (as a source of ammonium and phosphate) are considered to have the greatest potential for use, if required. Limestone and phosphate rock are low solubility solids and commercial fertilizers are generally high solubility solids or solutions.

The application options, which are considered to have the most potential for use in the application of the organic substrate (i.e. lactate, HRC, and vegetable oil) into the DCPRB 
contaminated groundwater, are an injection well system and/or use of the D-Area Interceptor Well, DIW-1, as an injection system. The application option, which is considered to have the most potential for use in the application of the limestone or phosphate rock, is a modified permeable reactive barrier (internal injection distribution system and not keyed into the green clay). Commercial fertilizer, if required as an ammonium source, could be added as necessary as a solid or liquid through the internal injection distribution system of the modified permeable reactive barrier.

\subsection{RECOMMENDATIONS}

Based upon the results of this literature review the following recommendations are made:

- It is recommended that sulfate reduction conducted adjacent to the D-Area Coal Pile Runoff Basin (DCPRB) combined with Monitored Natural Attenuation (MNA) be the DCPRB groundwater plume remedial approach taken. Sulfate reduction will raise the $\mathrm{pH}$ and significantly reduce the iron, aluminum, and other metal concentrations commensurate with subsequent use of MNA for complete plume remediation.

- It is recommended that phased laboratory and pilot scale testing be conducted to answer the following questions in relation to the sulfate reduction portion of the DCPRB remediation. That is these questions will be answered in phases during both the laboratory and pilot scale testing. Answers to all of the questions will not be pursued all at once, but the most important questions/answers will be addressed first.

- The primary question is, 'Can sulfate reduction, significantly increase the $\mathrm{pH}$ and reduce the metals concentration of the DCPRB groundwater plume?' All other questions help to answer this primary question.

- Are SRB present at the DCPRB, and if so, in what concentration and are they associated with the groundwater or soil? (This latter portion of the question addresses the issue of transport of SRB within the groundwater and potentially impacts the selection of the carbon substrate (i.e. miscible versus immiscible))

- Are other bacteria populations, necessary to facilitate sulfate reduction, present in the DCPRB groundwater?

- What is the best carbon substrate or combination of carbon substrates out of lactate, HRC, and vegetable oil to promote sulfate reduction for an extended time period in the vicinity of DIW-1?

- What is the optimal quantity of carbon substrate(s) for delivery to the DCPRB groundwater?

- Can the addition of the carbon substrate(s) alone promote efficient sulfate reduction under the current DCPRB groundwater $\mathrm{pH}$ conditions, or is the use of limestone and/or phosphate rock required to bring the $\mathrm{pH}$ up into the range optimal for SRB?

- What is the anticipated effectiveness over time of a limestone trench in raising the $\mathrm{pH}$ of the DCPRB groundwater (i.e. evaluate potential for limestone armoring and formation/limestone pluggage over time)?

- Does a micronutrient limitation (i.e. phosphate or nitrogen) exist under the current DCPRB groundwater conditions in relation to sulfate reduction? 
- What impact does the information gained during the laboratory and pilot scale testing have on the conceptual delivery system?

- It is recommended that an evaluation of the existing DCPRB limestone trench (DTT-1) be included as part of the laboratory and pilot scale testing. Such an evaluation should include monitoring the aluminum, calcium, and magnesium concentrations over time and monitoring the trench's specific capacity over time.

- It is recommended that the D-Area Interceptor Well (DIW-1) be utilized for the injection of the carbon substrate(s) during the phase pilot scale testing. It should be ideally suited for injection, is located in the most contaminated portion of the DCPRB groundwater plume, and has a sufficient existing monitoring system associated with it.

- If $\mathrm{pH}$ adjustment beyond that provided by the addition of a carbon substrate is required, it is recommended that a limestone trench be installed immediately upgradient of DIW-1 during the phase pilot scale testing.

- It is recommended that the following conceptual application system (delivery system) be adopted for the sulfate reduction remediation of the DCPRB to help guide the phased laboratory and pilot scale testing:

- The conceptual sulfate reduction delivery system in the most contaminated, far northwestern portion of the DCPRB should consist of the following:

* A limestone/phosphate rock filled trench with an internal injection distribution system will be located between the DCPRB and DIW-1 within the upper most low permeability portion of the water table aquifer (i.e. 20 to 25 feet deep) for $\mathrm{pH}$ adjustment and phosphate addition.

* DIW-1 will be utilized for the injection of the carbon substrate(s).

- The conceptual sulfate reduction deliver system along the western side of the DCPRB should consist of the following:

* A limestone/phosphate rock filled trench with an internal injection distribution system will be located immediately adjacent to the western DCPRB berm for $\mathrm{pH}$ adjustment and phosphate addition. The trench will be located within the upper most low permeability portion of the water table aquifer and extend down to the lower more permeable zones of the water table aquifer (i.e. 20 to 25 feet deep).

* A vertical injection well system will be utilized for the injection of the carbon substrate(s). The wells will be located downgradient from the trench and will be screened in the lower more permeable zones of the water table aquifer into which the trench directs the contaminated groundwater.

- It is recommended that the following additional questions be considered during the laboratory and pilot scale testing:

- Can MNA effectively handle the $\mathrm{pH}$ and metals concentration remaining after sulfate reduction treatment? 
- What is the potential for the remobilization of metals after the DCPRB groundwater geochemistry returns to more normal conditions?

- It is recommended that the following be considered in relation to any full scale implementation of sulfate reduction at the DCPRB:

- The continued use of the D-Area powerhouse and associated open coal pile, results in a continual influent of contaminated water to the DCPRB and subsequently a continual source of contamination to the groundwater. This situation must be appropriately considered for any full-scale implementation.

- The water levels and the groundwater flow direction and field will change when the DCPRB is removed from service.

- Any in situ system, including sulfate reduction and MNA, will be designed to immobilized the metal contaminates in the subsurface and as such will essentially preclude the removal of the immobilized metals from the subsurface.

- It is recommended that a treatability study work plan (TSWP) be prepared based upon this literature review for the implementation of the laboratory and pilot scale testing recommended within this report.

- Once discharge to the DCPRB is discontinued it is recommended that a base (preferably limestone) be blended into the basin soils to help immobilize the contaminants present. 


\section{REFERENCES}

Benner, S.G., D.W. Blowes, W.D. Gould. R.B. Herbert, Jr. and C.J. Ptacek. 1999. Geochemistry of a permeable reactive barrier for metals and acid mine drainage. Environmental Science and Technology. 33: 2793-2799.

Benner, S.G., W.D. Gould and D.W. Blowes. 2000. Microbial populations associated with the generation and treatment of acid mine drainage. Chemical Geology. 169: 435-448.

Chapelle, F. H., 1993, Ground-water microbiology and geochemistry, John Wiley \& Sons, Inc., New York.

Chynoweth, D.P., C.E. Turick, J.M. Owens, D.E. Jerger, and M.W. Peck. 1993. Biochemical methane potential of biomass and waste feedstocks. Biomass and Bioenergy. 5:95-111.

Ehrlich, H.L. 1996. In. Geomicrobiology. pp.312-367. Marcel Decker Inc. N.Y., N.Y.

EPA, 1999a. Microbial Processes Affecting Monitored Natural Attenuation of Contaminants in the Subsurface, EPA/540/S-99/001, United States Environmental Protection Agency, Washington, DC, September 1999.

EPA, 1999b. Field Application of In Situ Remediation Technologies: Permeable Reactive Barriers, EPA542-R-99-002, United States Environmental Protection Agency, Washington, DC, April 1999.

EPA, 2000. Coal Mining Best Management Practices Guidance Manual, EPA 821-R-00-007, United States Environmental Protection Agency, Washington, DC, March 2000.

Fauque, G.D. 1995. Ecology of sulfate reducing bacteria. pp. 217-235. In. Sulfate-reducing bacteria. (ed) L.L.Barton. Plenum Press. N.Y, N.Y.

Fenchel, T., G.M. King and T.H. Blackburn. 1998. In, Bacterial Biogeochemistry: the Ecophysiology of Mineral Cycling. pp 26-28. Academic Press, NY, NY.

Furrer, G., U. von Gunten and J. Zobrist. 1996. Steady-state modeling of biogeochemical processes in columns with aquifer material: 1. Speciation and mass balances. Chemical Geology. 133:15-28.

GeoChemical Information Management System (GIMS) database.

ITRC, 1998. Technical and Regulatory Requirements for Enhanced In Situ Bioremediation of Chlorinated Slovent in Groundwater, ISB-6, Interstate Technology Regulatory Cooperation Workgroup, In Situ Bioremediation Subgroup, December 23, 1998. 
Koenigsberg, S. S. (editor). 2001. Accelerated Bioremediation of Chlorinated Compounds in Groundwater: Selected Battelle Conference Papers 1999-2000, Regenesis Bioremediation Products, San Clemte, CA.

Leeper, S.A., T.E. Ward and G.F. Andrews. 1991. Production or organic chemicals via bioconversion: A review of the potential. DOE Report: EGG-BG-9033.

Lowry, W., Mason, N., Chipman, V., Kisiel, K., and Stockton, J., In-Situ Permeability Measurements with Direct Push Techniques: Phase II Topical Report, SEASF-TR-98-207, Science and Engineering Associates, Inc., Santa Fe, New Mexico, March 1999.

Phifer, M. A., Sappington, F. C., Pemberton, B. E., and Nichols, R. L., Interim Report D-Area Interceptor Well, DIW-1 Water Table Aquifer (U), WSRC-TR-99-00017, Revision 0, Savannah River Site, Aiken SC 29808, September 30, 1996.

Phifer, M. A., Sappington, F. C., and Denham, M. E., TNX GeoSiphon Cell (TGSC-1) Phase I Deployment / Demonstration Final Report (U), WSRC-TR-98-00032, Savannah River Site, Aiken SC 29808, February 27, 1998.

Phifer, M. A., and Denham, M. E., DEXOU Low pH Plume Baseline Permeable Reactive Barrier Options, WSRC-TR-2000-00146, Revision 0, Savannah River Site, Aiken SC 29808, May 5, 2000 .

Phifer, M. A., Nichols, R. L., Sappington, F. C., Steimke, J. L. and Jones, W. E., TNX GeoSiphon $^{T M}$ Summary Report (U), WSRC-TR-2001-00015, Savannah River Site, Aiken SC 29808, January 19, 2001.

Phifer, M. A., Sappington, F. C., and Jones, W. E., DCB-8C Step and Constant Rate Pump Tests - D-Area Unconfined Aquifer Hydraulic Parameter Estimation, SRT-EST-2000-00226, Savannah River Site, Aiken SC 29808, July 18, 2000.

Schank, S.C., D.P. Chynoweth, C.E. Turick, and P.E. Mendoza. 1993. Napiergrass genotypes and plant parts for biomass energy. Biomass and Bioenergy. 4:1-7.

Stephen, J.R. and S.J. Macnaughton. 1999. Developments in terrestrial bacterial remediation of metals. Current Opinion in Biotechnology. 10:230-233.

Thomas, R. C., Romanek, C. S., Coughlin, D. P., and Crowe, D. E., 1999. “Treatment of Acid Mine Drainage Using Anaerobic Constructed Wetlands: Predicting Longevity with Substrate Neutralization Potential," Proceedings of Sudbury '99 Mining and Environmental II Conference, Sudbury, Ontario, Canada, pages 449-458.

Tuttle, J.H., P.R. Dugan and C.I. Randles. 1969. Microbial sulfate reduction and its potential utility as an acid mine water pollution abatement procedure. Applied Microbiology. 17:297-302. 
Turick, C.E., M.W. Peck, D.E. Jerger, E.H.White, L. Zsuffa and D. P. Chynoweth. 1991. Methane fermentation of woody biomass. Bioresource Technology, 37: 141-147.

Washburn, F. A., Denham, M. E., Jones, W. E., Phifer, M. A., and Sappington, F. C., Permeable Reactive Barrier/Geosiphon Treatment System for Metals Contaminated Groundwater Final Report, WSRC-RP-99-01063, Revision 0, Savannah River Site, Aiken SC 29808, November, 1999.

Waybrant, K.R., D.W. Blowes and C.J. Ptacek. 1998. Selection of reactive mixtures for use in permeable reactive walls for treatment of mine drainage. Environmental Science \& Technology. 32:1972-1979.

White, C., A.K. Sharman and G.M. Gadd. 1998. An integrated microbial process for the bioremediation of soil contaminated with toxic metals. Nature Biotechnology. 16:572-575.

WSRC, RCRA Facility Investigation/Remedial Investigation Work Plan - Addendum for the DArea Expanded Operable Unit (U), WSRC-RP-99-4067, Revision 0, Savannah River Site, Aiken SC 29808, October, 1999.

WSRC, F-Area Seepage Basins In-Situ pH Adjustment Field Test Plan, WSRC-TR-2001-00258, Savannah River Site, Aiken SC 29808, May 23, 2001.

von Gunten, U and G. Furrer. 2000. Steady-state modeling of biogeochemical processes in columns with aquifer material; 2. Dynamics of iron-sulfur interactions. 167: 271-284. 


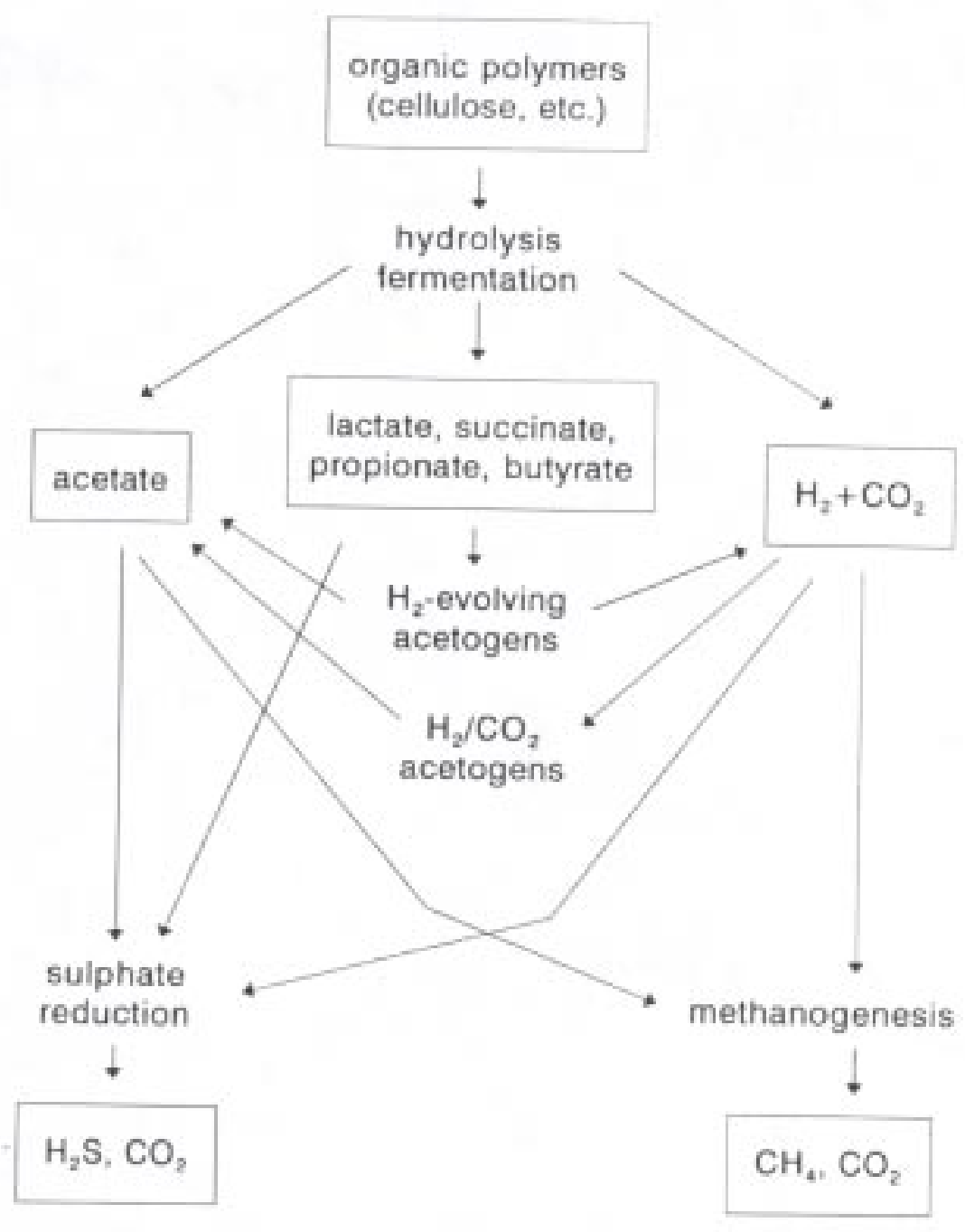

Figure 1, Organization and Carbon Flow of a Microbial Community of Fermenters, Sulfate Reducers and Methanogens (Fenchel, et al. 1998) 


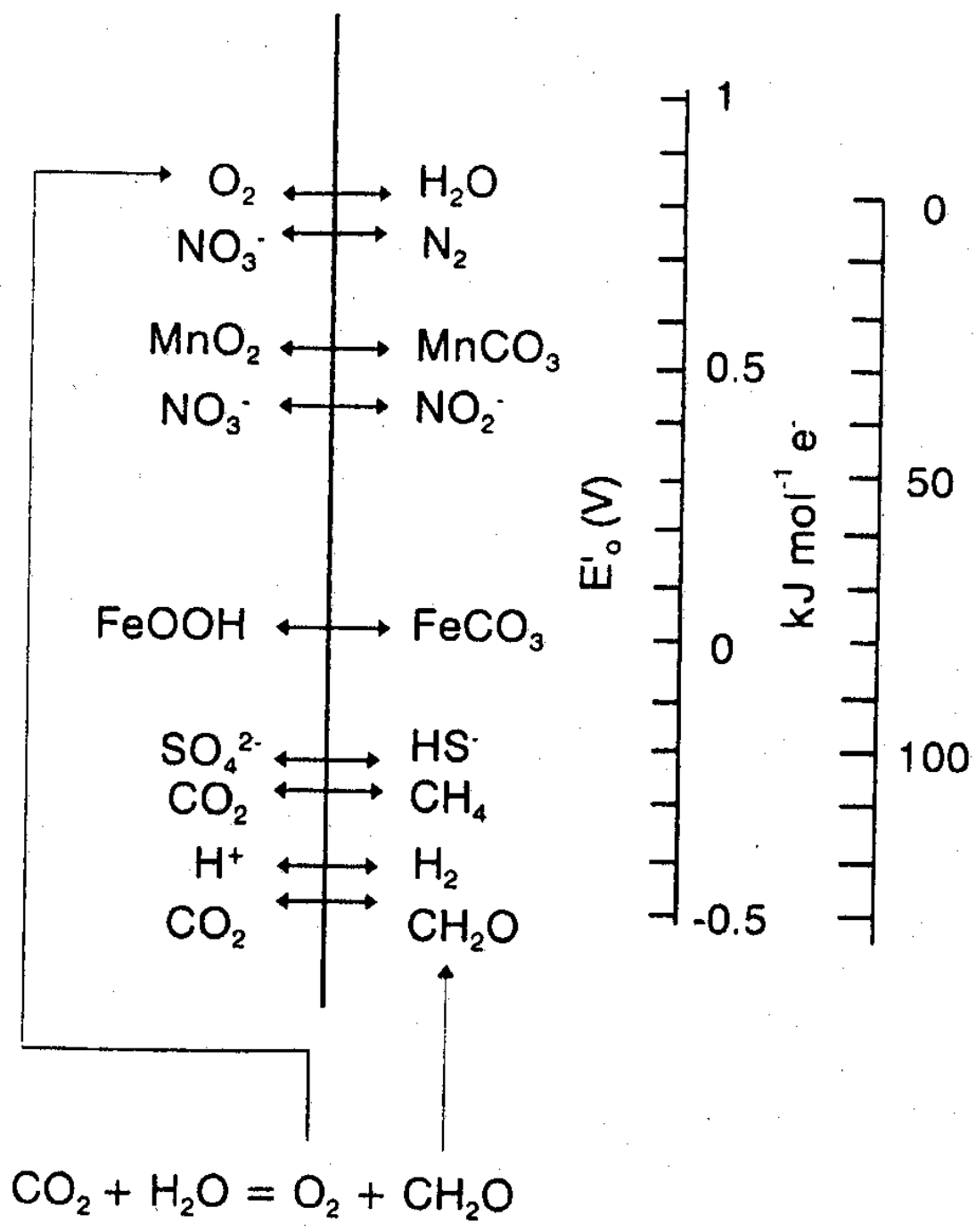

Figure 2, Standard Redox Potentials (pH 7) of some Important Redox Couples and Free Energy Changes Involving Two Redox Couples in Respiratory Processes and $\mathrm{H}_{2} / \mathrm{CO}_{2}$ Methanogenesis

(Fenchel, et al. 1998) 


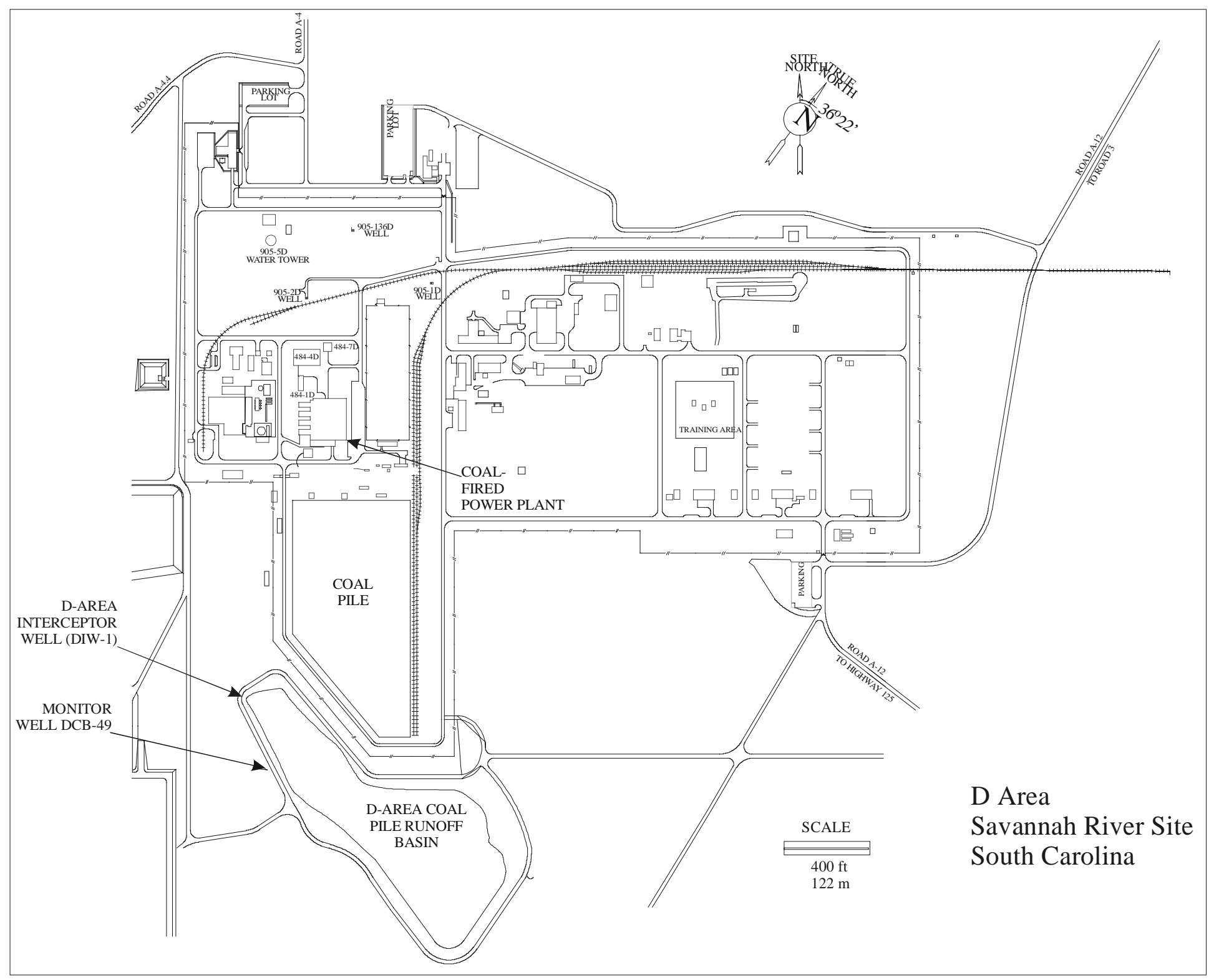

Figure 3, D-Area Coal Pile Runoff Basin Location Map 


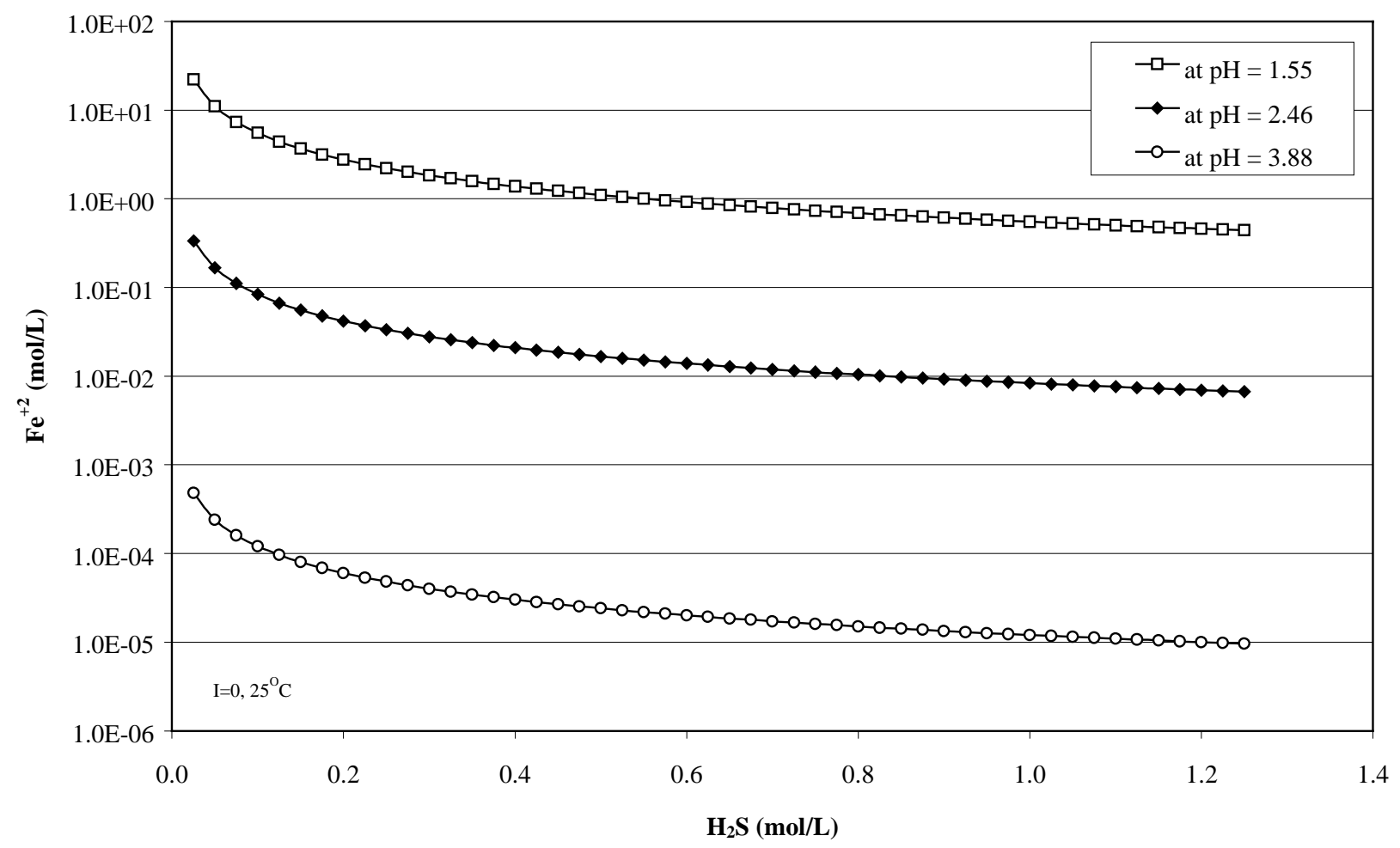

Figure 4, Ferrous Monosulfide Solubility

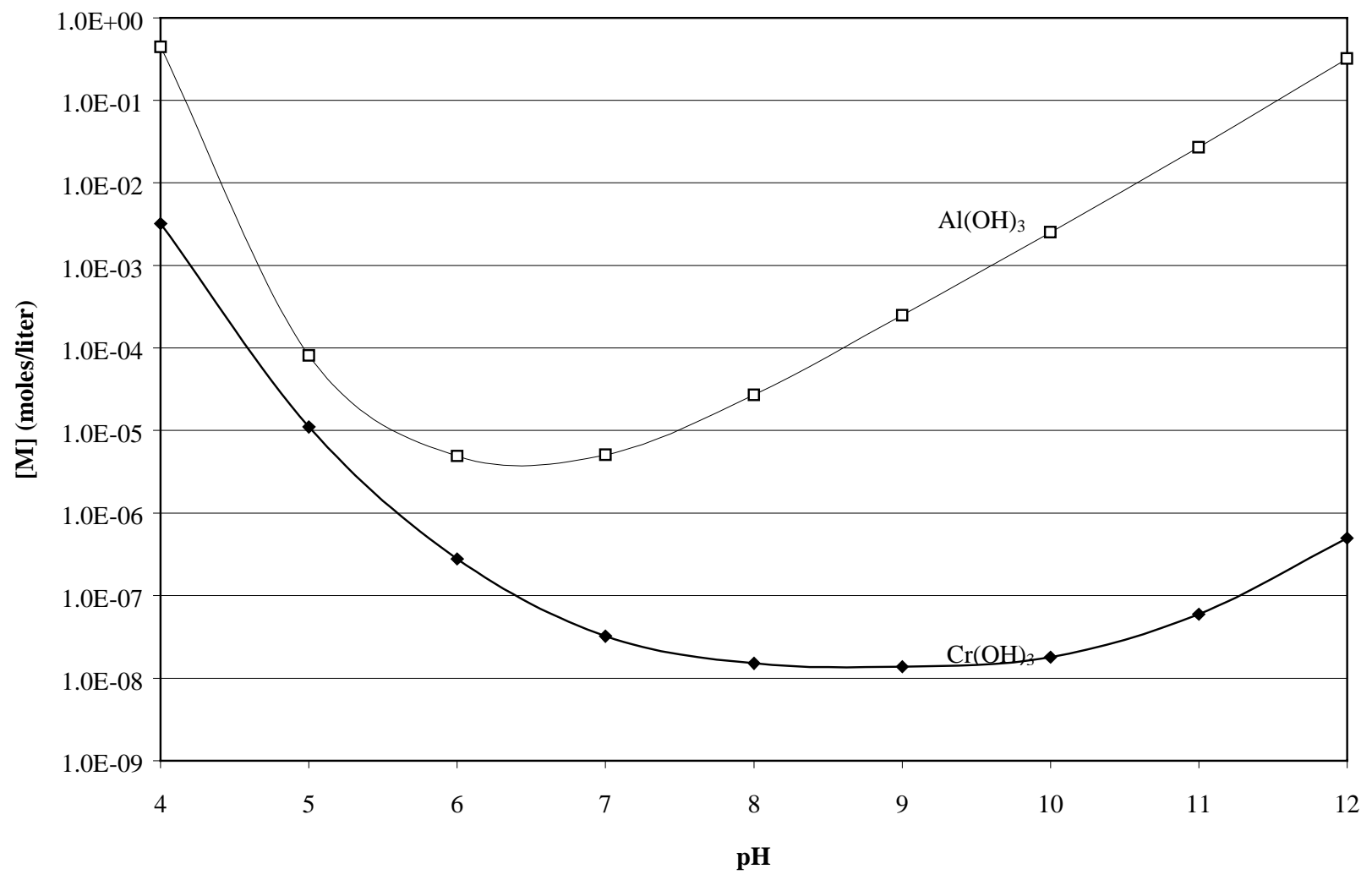

Figure 5, Aluminum and Chromium Hydroxide Solubility 


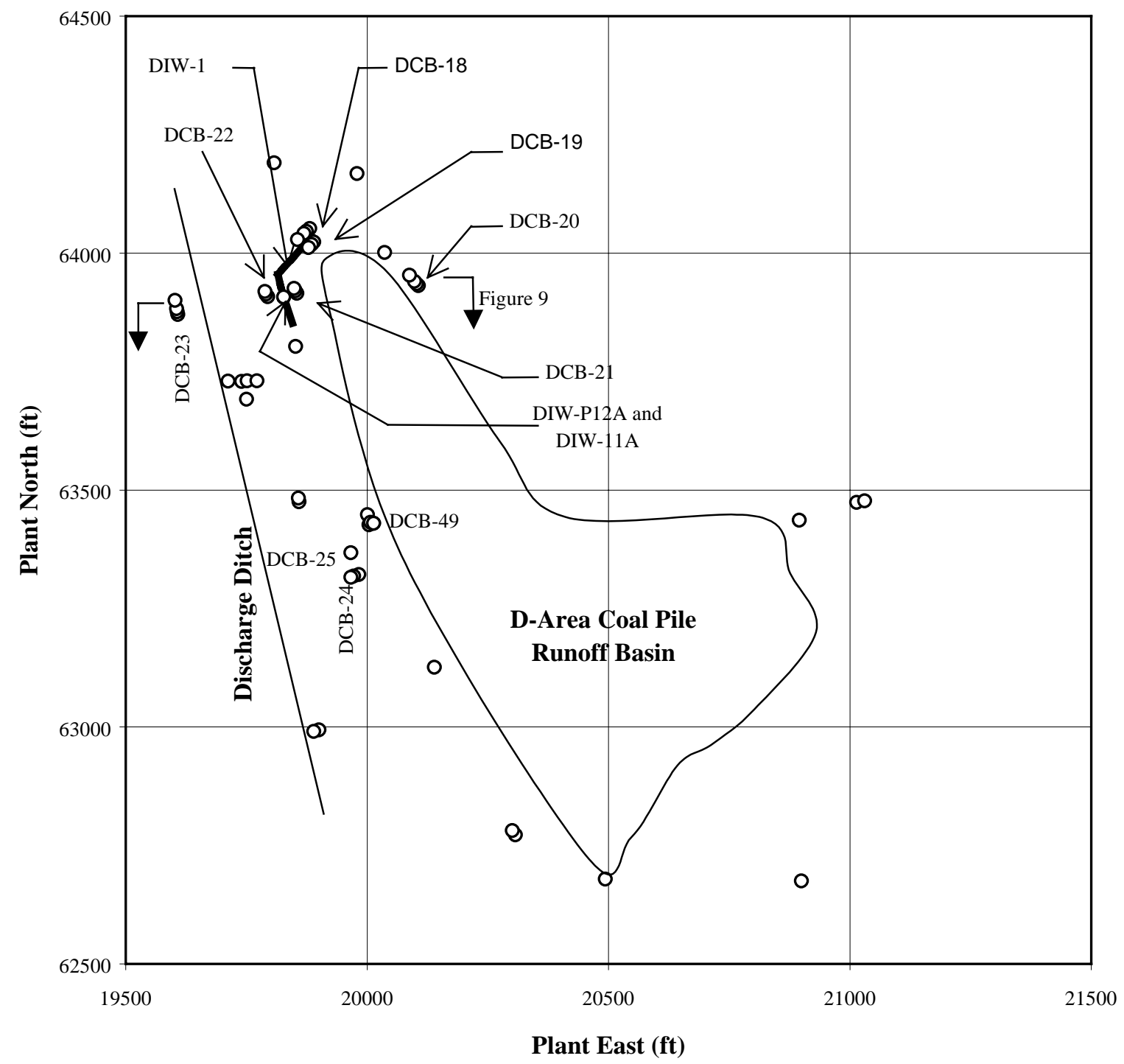

Figure 6, Selected DCPRB Wells 


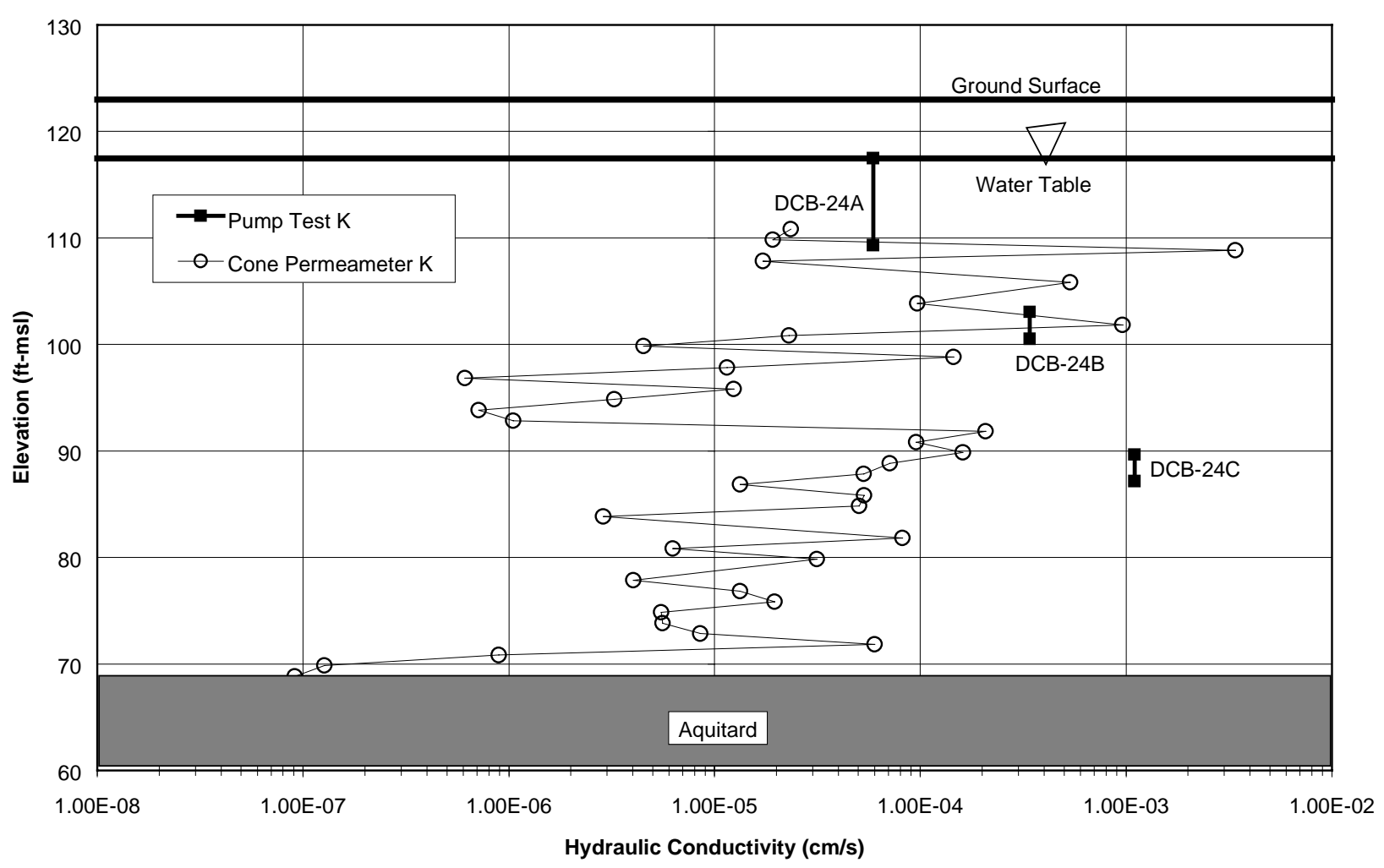

Figure 7, DCPRB Water Table Aquifer Hydraulic Conductivity Profile

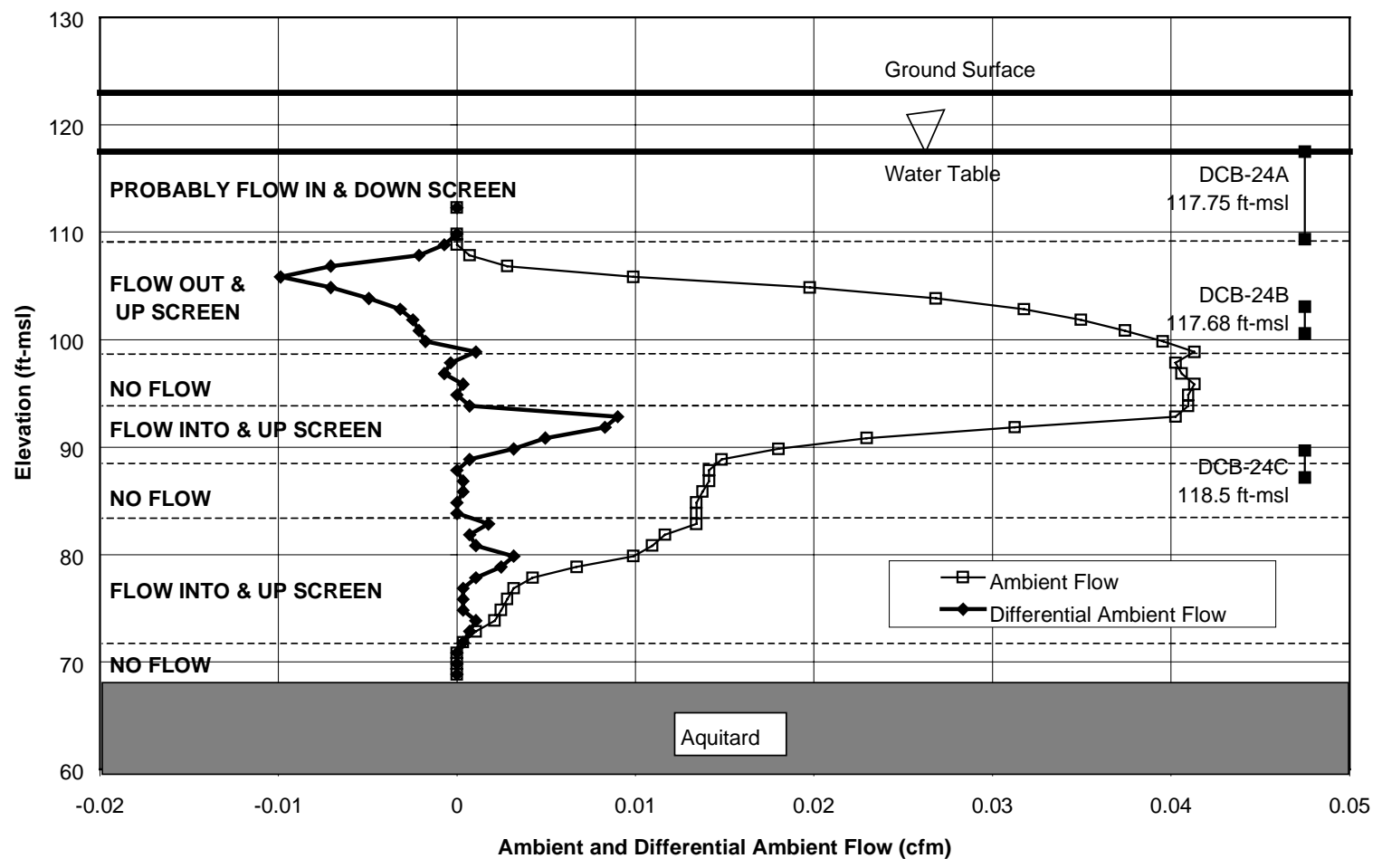

Figure 8, DCB-25 Ambient and Differential Ambient Flows (7/31/96) and DCB-24A, B, and C Heads (1/25/96) 


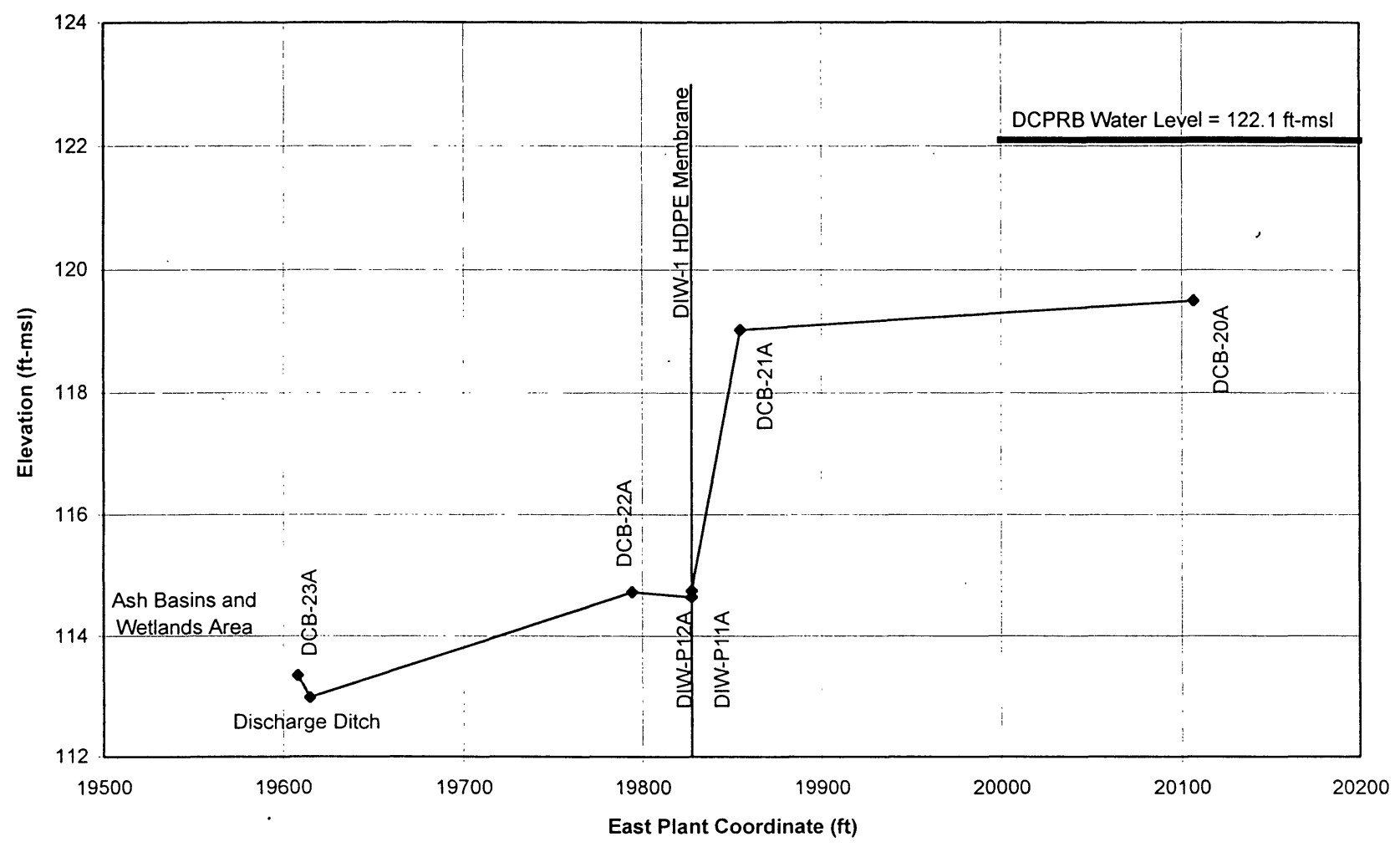

Figure 9, Water Table Profile across DIW-1

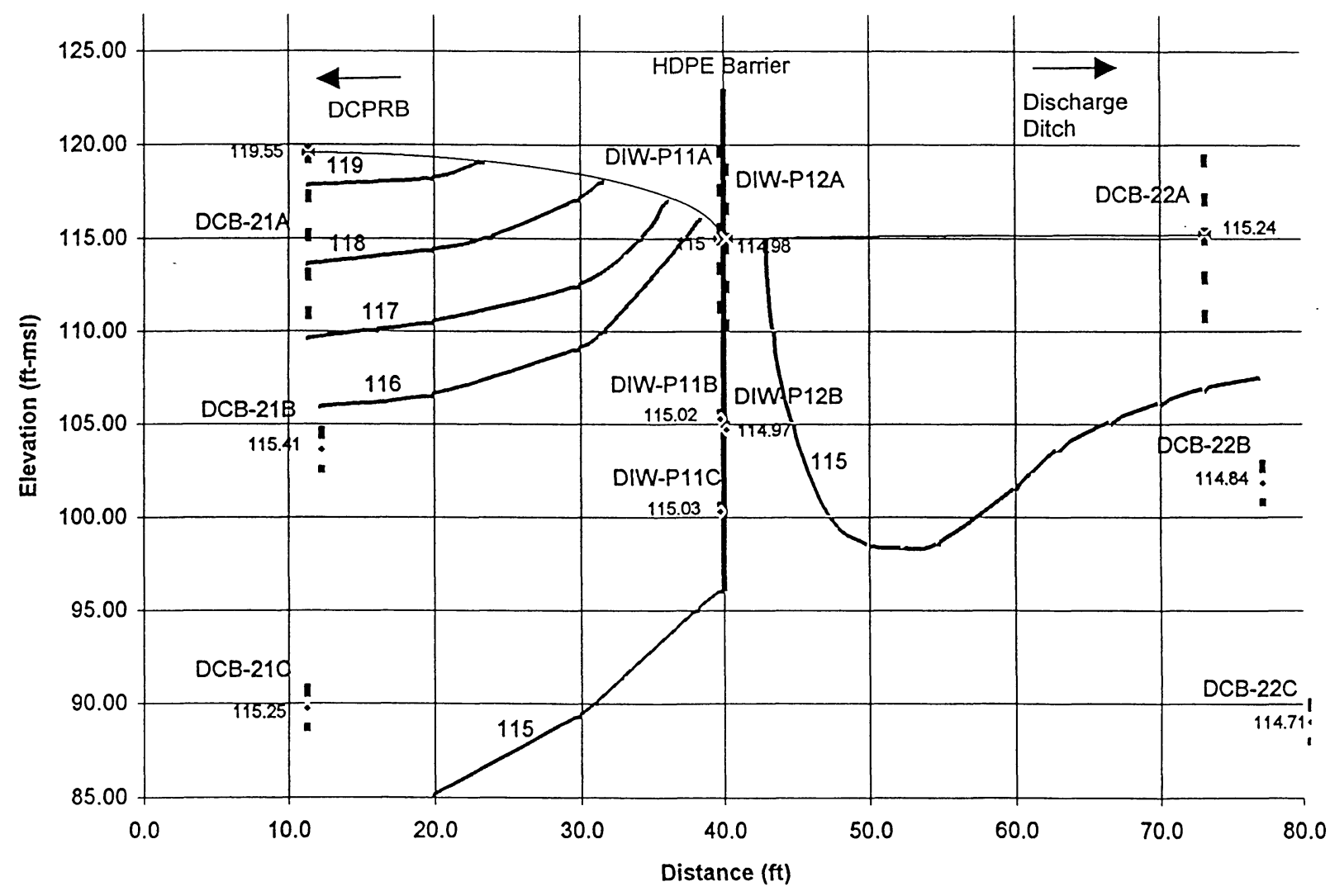

Figure 10, Head Cross Section across DIW-1 